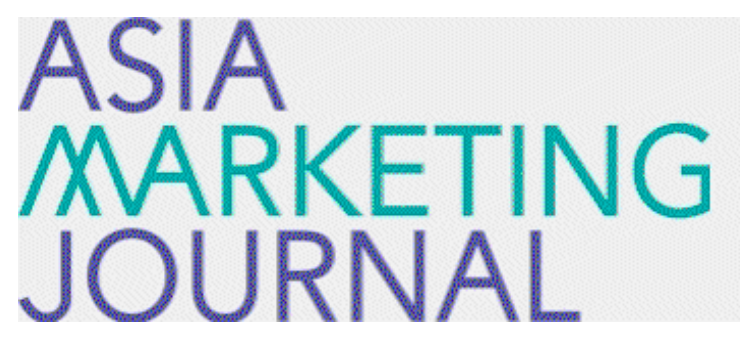

ASIA MARKETING JOURNAL

Volume 9 | Issue 3

Article 8

10-30-2007

\title{
세계 최초 알칼리수 소주, <처음처럼>
}

Heung Soo Park

Dong Hoon Kim

Dong Jin Lee

Follow this and additional works at: https://amj.kma.re.kr/journal

Part of the Marketing Commons

\section{Recommended Citation}

Park, Heung Soo; Kim, Dong Hoon; and Lee, Dong Jin (2007) "세계 최 초 알칼리수 소주, <처음처림 >," Asia Marketing Journal: Vol. 9 : Iss. 3 , Article 8.

Available at: https://doi.org/10.53728/2765-6500.1204

This Article is brought to you for free and open access by Asia Marketing Journal. It has been accepted for inclusion in Asia Marketing Journal by an authorized editor of Asia Marketing Journal. 


\title{
세계 최초 알칼리수 소주, 〈처음처럼〉 \\ - 웰빙 소주를 통한 시장 분할 -
}

\section{Marketing Strategy of Cheo-um-cheo-rum}

\author{
박 홍 수(Park, Heungsoo)* \\ 김 동 훈(Kim, Donghoon)** \\ 이 동 진(Lee, Dong-Jin) $)^{* * *}$
}

두산은 2001년에〈산〉 소주 제품으로 소주시장에 진입하였지만, 2002년도에 $6.7 \%$ 였던 〈산〉 소주의 시장 점유율이 2004 년도 들어서서 $5.4 \%$ 로 하락하였고, 선호도 역시 매우 낮은 수준으로 조사되어, 원인분석과 함께 새로운 소주에 대한 개발 필요성이 대두되었다. 당시 두산은 시장 선도 브랜드인 〈참이슬〉의 충성 고객층은 감소하면서 비호감 고객층이 증가하는 등 소주에 대한 고객의 욕구가 변 화하고 있다는 시장조사 결과에서 성공의 기회를 엿볼 수 있었다. 그리고 1 인당 알코올 소비량은 감 소하였으나 소주의 소비량은 연간 70병으로 일정한 소비를 나타나고 있었기 때문에, 소주시장의 매력 도는 아직 충분히 존재한다고 판단하였다. 그리하여 두산이 목표로 삼을 표적시장 선정을 위한 시장 조사를 대대적으로 시작하였는데, 소주 음용 조사에서 30 40대의 남성들은 소비량이 감소하는 반면 여성들의 소주 소비량은 전 연령대에 걸쳐 증가하는 것으로 나타났다. 여기에서 두산은 새로운 소주 시장에 대한 신제품 개발의 기회를 발견하고, 신제품 개발 프로젝트에 착수하게 되었다. 이를 위해 먼저 소주 트렌드의 변화와 소비자들의 라이프 스타일을 살펴보고, 이를 통해 '웰방'을 신제품의 주요 가치로 결정하게 된다. 이후 시장 세분화 조사를 통해 다량음용자(heavy user)가 많은 품질 중시 시 장과 도수 및 숙췩 중시 시장에 진입하기로 한다. 그 다음 소주에 대한 소비자들의 불만족 요인이 무 엇인지 살펴보고 이를 해결하기 위한 대안들을 탐색한다. 그 결과 '목 넘김이 부드럽고, 몸의 산성화 롤 중화시키며, 숙취 해소'에 뛰어난 '알찰리수'를 신제품의 주원료로 사용한〈처음처럼〉을 개발하게 된다. 소주의 주요 속성별 선호도 조사를 실시한 결과, 모든 속성에서〈처음처럼〉이 경쟁사 제품보다 뛰어난 것으로 나타나 두산은 〈처음처럼〉을 시장에 출시하게 되었다. 〈처음처럼〉은 24 35세를 목표 고객으로 설정하고, 유흥업소가 밀집한 중심상권을 집중적으로 공랴하였다. 이를 위해 저가 정책을 실시하여 유통업체의 마진을 높였으며, 다양한 광고, 촉진 전략을 통해서 소비자 인지도를 향상시켰

* 연세대학교 경영대학 교수(hspark@base.yonsei.ac.kr)

** 연세대학교 경영대학 교수(dhkim@yonsei.ac.kr)

*** 연세대학교 경영대학 교수(djlee@base.yonsei.ac.kr) 
다. 그 결과 수도권 및 전국 지역에서 지속적으로 시장점유율이 증가하였으며, 소비자들에게〈참이 슬〉과 차별화된 이미지를 구축하게 되었다. 〈처음처럼〉이 성공적으로 시장에 진입할 수 있었던 이유 로는 알칼리수 사용, 감성적 브랜드명 채택, 차별화된 마케팅 전략 구사. 그리고 조직원의 강력한 성 공 의지 등을 들 수 있다. 소주 시장의 독보적 존재였던 〈참이슬〉과의 경쟁에서 이루어진 결과라는 점에서〈처음처럼〉의 사례는 많은 기업들에게 시사점을 제공할 수 있다. 하지만 현재 '대중성'이나 '친근감'같은 이미지가〈참이슬>에 비해 상대적으로 낮고, 〈참이슬 fresh〉의 출시로 인해 목표 고객인 20 대가 이탈되는 문제는 앞으로〈처음처럼〉이 극복해야 할 과제이다. 이를 위해〈처음처럼〉은 무엇보 다 '웰빙 소주’로서의 이미지를 확고히 하기 위한 마케팅 전락을 실행하여야 할 것이다.

핵심개념: 주류산업, 웰빙소주, 알카리 환원수, 신제품개발, 시장세분화

\section{I. 주류 산업 이해}

\section{1 기업 소개}

(주두산 주류 $\mathrm{BG}$ 는 제품 세분화된 시장을 대 상으로 제품을 차별화하여, 소주 시장, 청주 시 장, 매실주 시장, 와인 시장에 진출한 상태이다. 또한, 청주 시장에서는 〈청하〉, 매실주 시장에 서는〈설중매〉, 와인 시장에서는〈마주앙〉과 같 이 각 세분 시장을 대표하는 선두브랜드를 보 유하고 있다.

특히, 〈청하〉, 〈백화수복〉, 최고급 수제〈청주 설화> 등의 청주 및 주정을 생산하는 국내 최 대규모의 군산공장, 〈마주앙〉, 〈설중매〉 등의 와인과 과실주를 생산하는 경산공장, 그리고 〈처음처럼〉을 생산하는 대관령 기슭의 강릉공 장이 가동하고 있다. 그리고 국내 최고의 연구 진으로 구성된 R\&D 주류연구소에서 고객이 원하는 제품을 개발, 생산하기 위하여 많은 노 력을 기울이고 있다. 그 결과 제품의 기술력과 품질을 인정 받아 (주) 두산 주류 $\mathrm{BG}$ 는 국내뿐만
세계 40여 개국에 수출되고 있으며, 이 중 소주 는 2004년부터 일본 수출 1위를 달성하였다.

\section{2 주류 유통구조}

주류는 일반적으로 제조회사, 도매상, 소매상 의 과정을 통해 유통되는데, 크게 세 가지 경로 를 통해 이루어진다. 첫 번째로 주류 도매상을 통해서 대중식당이나 고깃집, 일식집, 생맥주집 과 같은 유흥업소로 유통되는 경우가 가장 많 은데, 주류 도매상은 전국적으로 1,200 개소에 이르며, 유흥 업소는 약 430,000 개소 가량 된다. 두 번째로 많은 경로는 슈퍼마켓 본부를 통해 서 가정 업소로 유통되는 경우이다. 이 때, 슈 퍼마켓 본부는 300 여 개정도 있으며, 대형할인 점, 편의점, 슈퍼마켓과 같은 가정 업소는 103,000 여개 정도 된다. 세 번째 경우는 특수 거래처를 통해 유통되는 구조이다.

\section{3 주류 산업 시장}

주류 산업 시장은 크게 맥주, 소주, 위스키, 
기타로 구분되는데, 매출액은 맥주>소주>위스 키〉기타의 순으로 이루어진다. 대한주륙공업협 회에서 발표한 2001년과 2005년의 매출액 규모 를 비교해 보면, 맥주가 $39.40 \%$ 에서 $38.20 \%$ 로. 위스키 $21.60 \%$ 에서 $19.60 \%$ 로, 기타 12.75 에서 $12 \%$ 로 전반적으로 감소하는 추세를 나타내고 있다. 반면 소주는 $26.3 \%$ 에서 $30.3 \%$ 로 다른 주 류들과 다르게 매출액이 성장하고 있다.

\section{II. 〈처음처럼〉개발 배경 및 시장 기회}

\section{1 선호도 조사}

두산에서는 신제품을 개발하기에 앞서 먼저
여러 소주 브랜드에 대한 소비자 선호도 조사 를 실시하였다. 조사 대상은 주류의 주요 소비 자인 20 40대의 성인 남녀이며, 조사 제품은 〈참이슬〉,〈진로〉,〈산〉,〈그린〉,〈시원〉,〈잎새 주〉로 총 6 가지 제품으로써. 이들 제품에 대한 소비자들의 선호도를 조사하였다.

선호도 조사 결과를 살펴 보면, 〈참이슬〉은 모든 연령에서 $70 \%$ 이상의 선호도를 유지하며 압도적인 우위를 점하고 있다. 그 다음으로는 〈산〉이 평균 $7.5 \%$ 안팎의 선호도를 유지하고 있 어 2 위를 달리고 있지만, 1 위인〈참이슬〉과의 격차가 너무 커, 사실상 소주 시장은〈참이슬〉 이 독점적으로 지위를 차지하고 있다. 〈시원〉이 나.〈진로〉,〈잎새주〉, 〈그린〉과 같은 제품들은 연령대별로 차이를 나타내긴 하지만, 대부분 낮 은 선호도를 보이고 있다. 이 외에 전체 중 $8 \%$ 정도는 선호하는 제품이 없다고 답변하여, 이들

〈그림 1〉 소주 브랜드 별 소비자 선호도

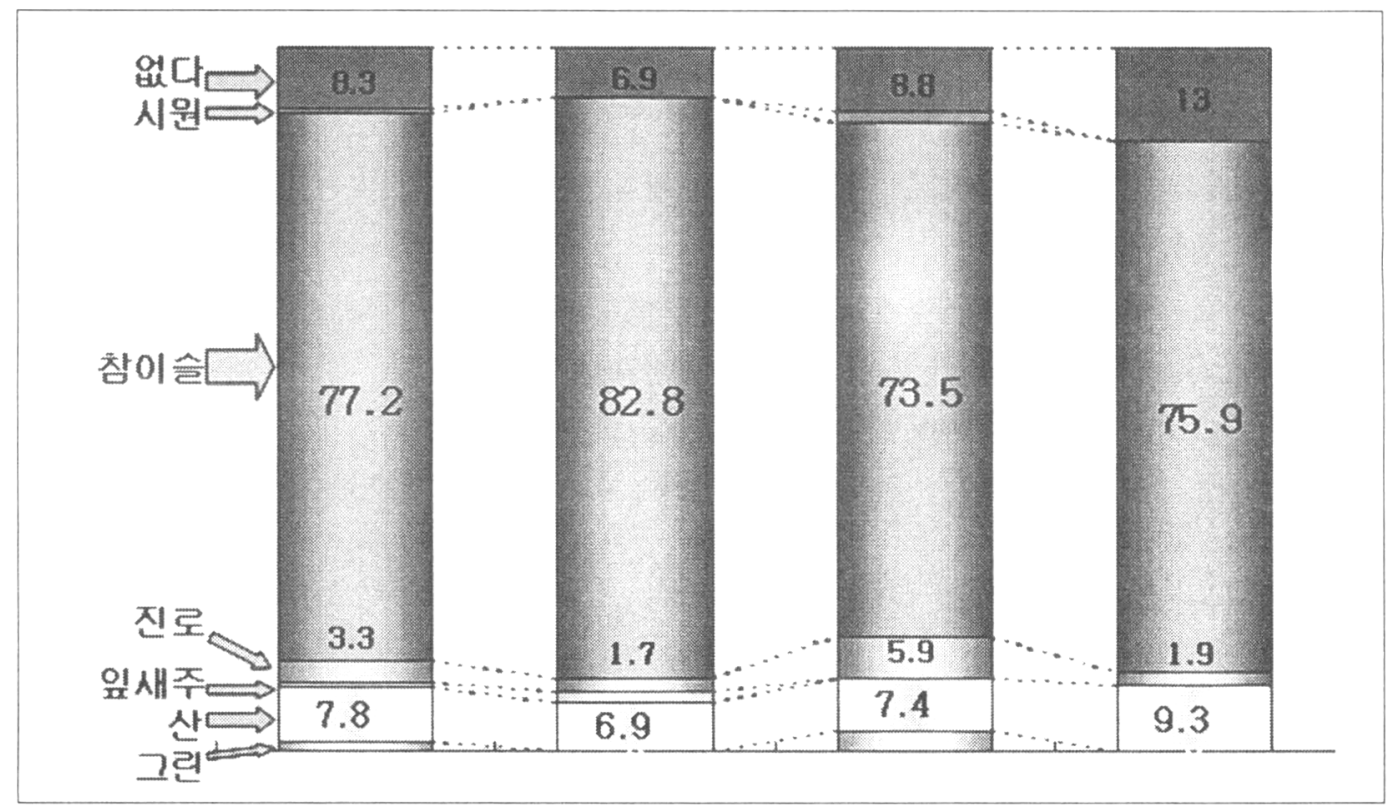


이 지닌 소주에 대한 욕구는 충족되고 있지 않 음을 짐작할 수 있다.

\section{2 산소주 시장 점유율의 정체}

두산의 대표적 소주 제품인 〈산〉 소주의 경우 사입율은 $90 \%$, 인지율은 $70 \%$ 로 매우 높은 수 준을 보이고 있다. 하지만 정작 시장 점유율은 2001 년에 6.4\%, 2002년에 6.7\%, 2003년에 5.6\%, 2004 년에 $5.4 \%, 2005$ 년에 $5.6 \%$ 로 최근 5 년간 평균 $5 \%$ 대에서 정체하고 있는 것으로 나타나 고 있다. 위의 조사에서도 나타나듯이 〈산〉의 선호도는〈참이슬〉에 비해 상대적으로 매우 낮 은 상태에 있다. 이는〈산>이 지닌 제품력 자체 의 한계로 인한 결과로서, 이를 위해 신제품 개 발을 고려하게 되었다.

\section{3 시장 상황}

두산은 신제품 개발을 위해 당시 시장 상황에 대해 외부적으로는 위협 요인과 기회 요인을 살펴보았다. 위협 요인은 무엇보다도 진로가 거 대 맥주 제주 회사인 하이트와 합병함으로써, 유통력이 증대되고 시장 관리 커버리지가 확대 되었다는 것이다. 반면에 〈참이슬〉의 충성 고객 이 최근 5 년간 $20 \%$ 에서 $11.3 \%$ 로 감소하고 있 으며, 〈참이슬>에 대한 비호감층이 $4.1 \%$ 에서 $7.9 \%$ 로 증가한다는 것은 소주에 대한 소비자의 욕구가 변화하는 동시에 새로운 욕구가 증가된 다는 것으로 두산에게는 큰 기회 요인으로 작 용할 수 있다.

\section{4 국내 인구 변화 추이}

국내 인구는 2000년 이후 지속적인 정체를 나 타내고 있는 상태이고, 2023년을 정점으로 총인 구는 감소할 전망이다. 우리 나라는 세계 최저 의 저출산율( 1 가구 1.17 명)로 인해 고령화가 매 우 빠르게 진행되고 있으며, 진행 속도면에서는 대표적 고령화 사회인 일본을 능가하기에 이르 렀다.

연령대별 인구 비중 추이를 살펴보면, 10 20 대는 1990년 45\%, 2003년 32\%로 나타나고 있 는데 2010 년에는 $30 \%$ 로 감소할 것으로 예상된 다. 30 40대는 1990년 39\%, 2003년 48\%이며, 2010년에는 $45 \%$ 로 2003년 이후 정체될 것으로 보인다. 50대 이상 연령대를 살펴 보면, 1990년 $16 \%$. 2003년 19\%, 2010년 25\%로 지속적인 증 가 추세에 있다. 특히 50 대 이상 연령대는 현재 까지는 낮은 비중으로 인해 주류 산업에서의 중요도가 낮았지만, 향후 차지하는 인구 비중이 증가함에 따라 '노령층 시장(senior market)'이 될 가능성을 엿볼 수 있다.

\section{5 국내 소득/지출 변화 추이}

1990 년부터 2002년까지의 국내의 GCP와 GNI, 그리고 1 인당 $\mathrm{GNI}$ 및 가구 소득, 가구 지출, 그리고 가구 지출에 대한 항목구성 비중에 대 해 살펴보았다. 자료에 따르면 $\mathrm{GDP}$ 와 GNI, 가 구 소득 및 지출의 성장률은 정체되어 있음을 알 수가 있다.

가구 지출 항목과 구성 비중을 살펴 보면 흥 미로운 사실을 발견할 수가 있는데, 전반적인 식료품(식자재) 구입 비중은 감소한 반면(32.2\% 
〈그림 2〉 생산 인구 변화 추이

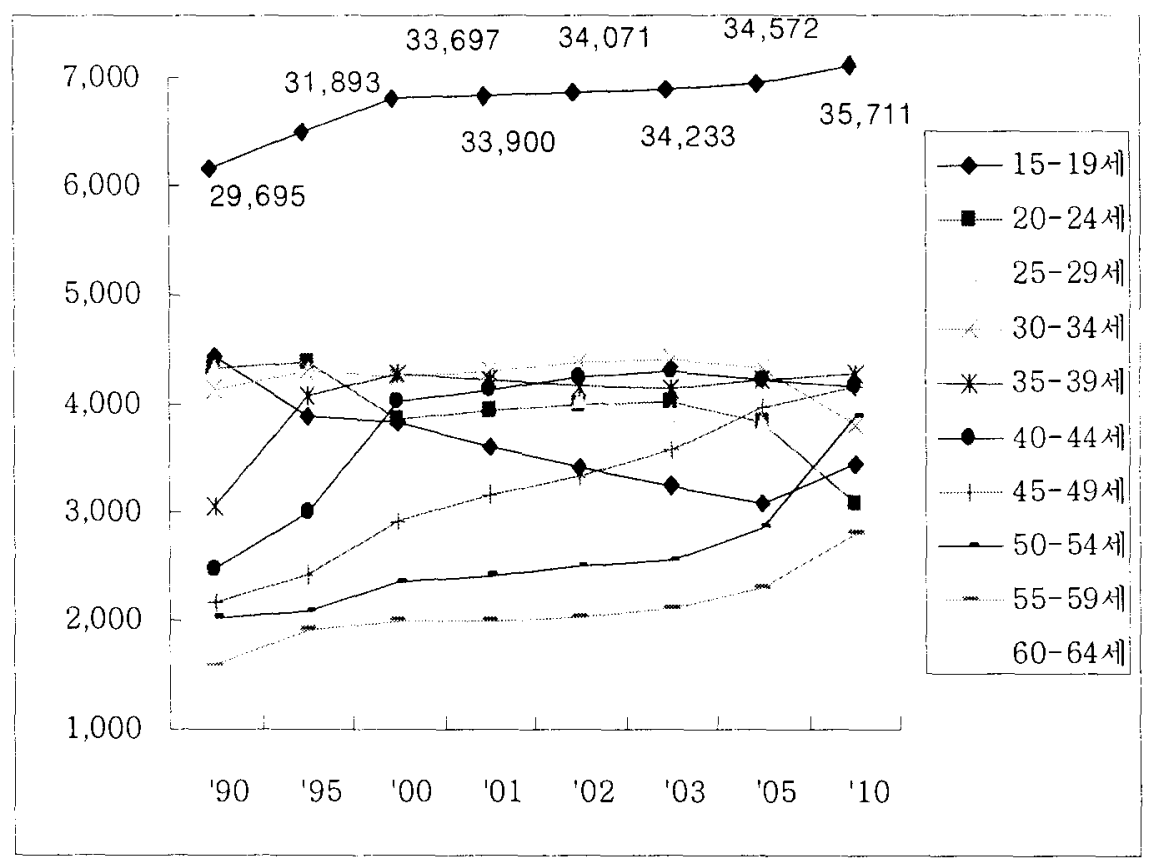

〈그림 3〉 인구 비중 변화 추이

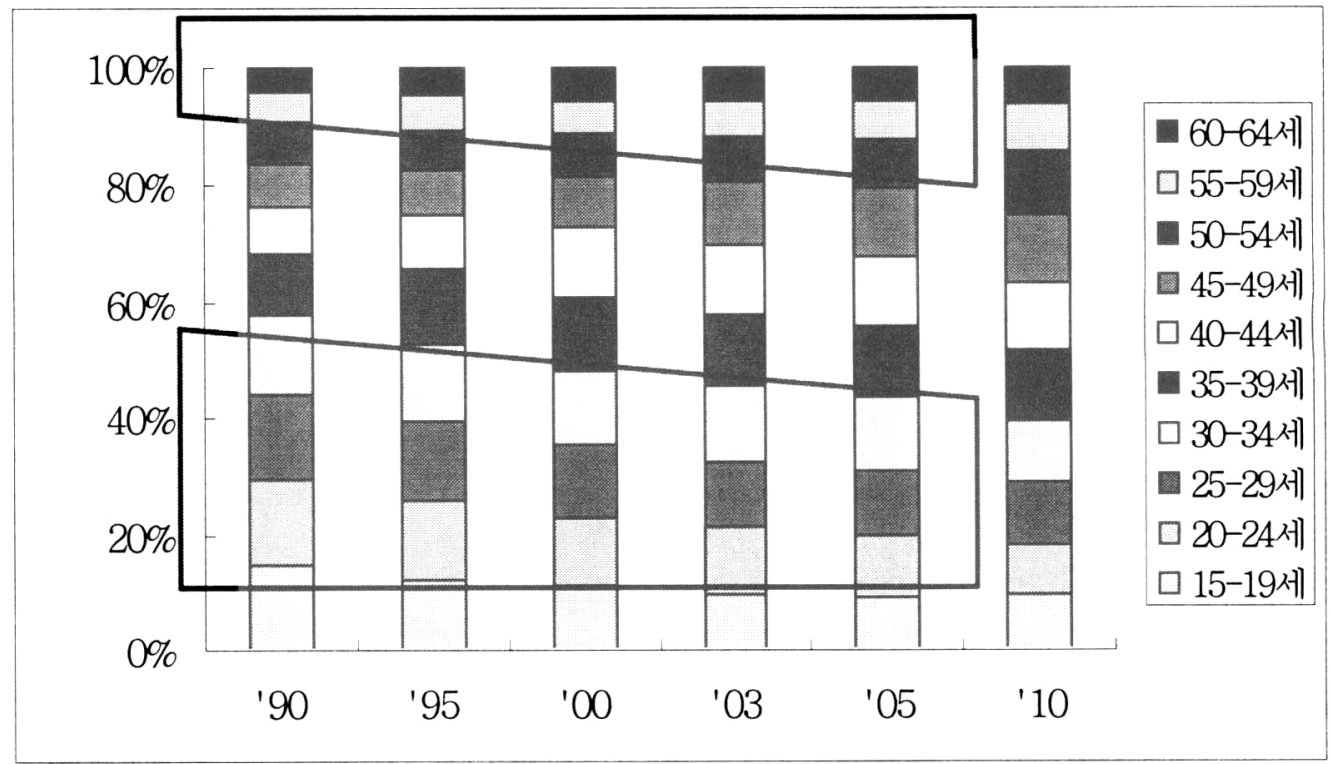


〈표 1〉 주요 소득 및 지출 지수 변화 추이

\begin{tabular}{|c|c|c|c|c|c|}
\hline & $\begin{array}{c}\mathrm{GDP} \\
\text { (단위:10억원) }\end{array}$ & $\begin{array}{c}\mathrm{GNI} \\
\text { (단위:10억원) }\end{array}$ & $\begin{array}{c}\text { 1인당 GNI } \\
\text { (단위:만원) }\end{array}$ & $\begin{array}{c}\text { 가구 소득 } \\
\text { (단위:천원) }\end{array}$ & $\begin{array}{c}\text { 가구 지출 } \\
\text { (단위:천원) }\end{array}$ \\
\hline 1990 & 178,797 & 178,628 & 417 & 945 & 685 \\
\hline 1995 & 377,350 & 376,316 & 835 & 1,911 & 1.266 \\
\hline 2000 & 521,959 & 519,227 & 1,105 & 2.387 & 1,632 \\
\hline 2001 & 551.558 & 550,014 & 1,162 & 2.625 & 1,762 \\
\hline 2002 & 596,381 & 596,881 & 1,253 & 2.792 & 1,835 \\
\hline
\end{tabular}

〈그림 4〉 가구 지출 항목 및 비중

\begin{tabular}{|c|c|c|c|c|c|c|c|}
\hline \multicolumn{8}{|l|}{$100 \%$} \\
\hline \multicolumn{8}{|c|}{ 식료품비 } \\
\hline \multicolumn{8}{|c|}{ 보건의료 } \\
\hline & & & & & 재개 & 267 & 116 \\
\hline $40 \%$ & & $9.1 \%$ & $10.8 \%$ & $10.8 \%$ & $11.0 \%$ 외식 & 447 & 176 \\
\hline \multirow{2}{*}{$20 \%$} & 20 & & & & & 464 & 190 \\
\hline & & & & & 식표훔 & 481 & 202 \\
\hline \multirow[t]{2}{*}{$0 \%$} & & & & & & \multicolumn{2}{|c|}{ (단위: 천원) } \\
\hline & '90 & '95 & '00 & '01 & '02 & & \\
\hline
\end{tabular}

$\rightarrow 26.2 \%$, 외식비는 오히려 2배 가까운 증가 추세를 나타낸다는 것이다 $(6.5 \% \rightarrow 11.0 \%)$. 이는 식생활이라는 동일 선상에서도 기본적 욕구와 관련한 소비보다는 “즐거움, 휴식, 인화” 등의 의미를 가미한 제품군의 소비 비중이 증가한다 는 것이다. 즉 이제 단순히 제품의 기본적 욕구 만을 충족시키는 제품으로는 소비자를 유인하 기가 어럽다는 것으로 해석할 수 있다. 따라서
주류 역시 제품의 맛, 원로, 주질 등과 같은 기 본적인 요소뿐만 아니라 건강, 유행, 선도성 등 과 같은 부가적이고 정서적인 욕구를 충족시켜 야 할 것이다.

\subsection{1 인당 알코올 소비량 추이}

〈그림 5〉는 1990년 2001년까지 주요 OECD 
〈그림 5〉 $\mathrm{OECD}$ 국가의 1 인당 알코올 소비량 추이

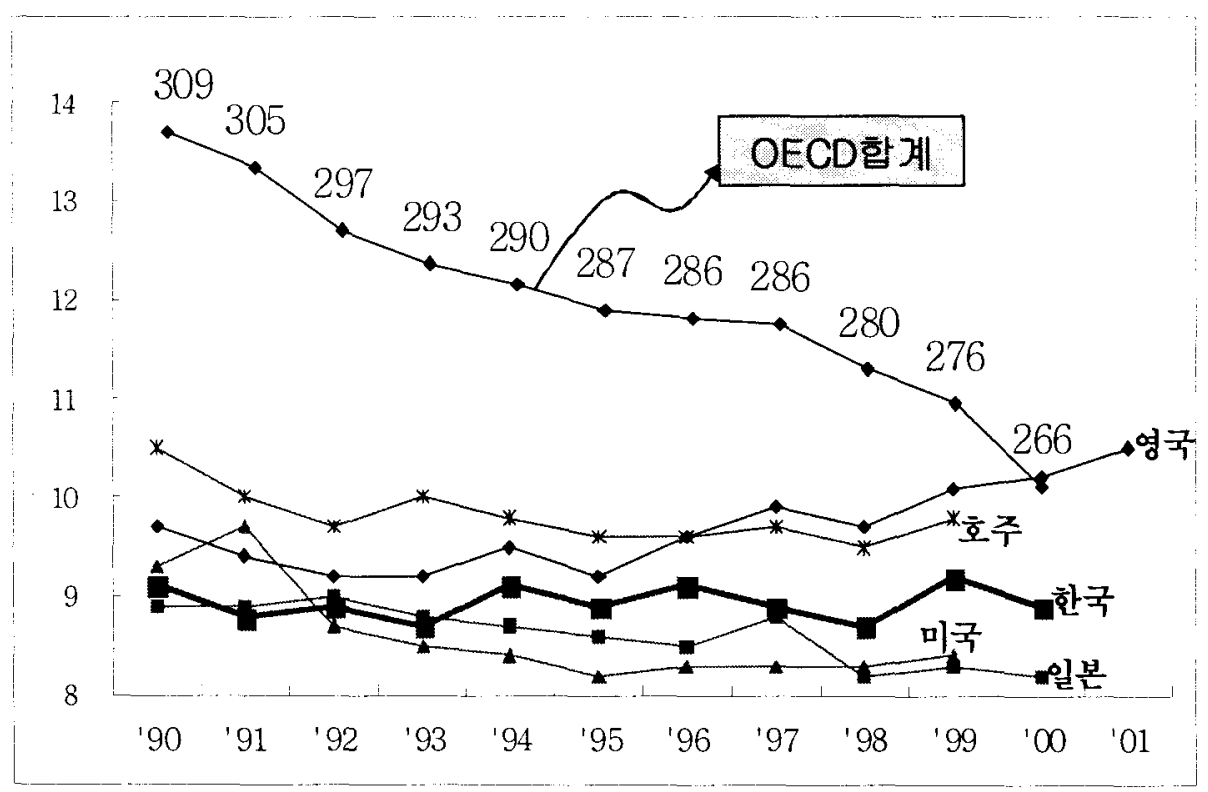

생산인구 기준, ${ }^{*} 100 \%$ 알코올 환산(단위: L)

국가들의 1 인당 알코올 소비량 추세를 나타낸 것이다. 이를 보면 영국을 제외한 한국, 일본, 미국, 호주 네 나리 모두에서 1인당 알코올 소 비량이 감소하고 있음을 알 수 있다. 우리 나라 의 경우 1 인당 알코올 소비량은 경기 변동에 따라 다소 등락의 여지가 있기는 하나. 소비량 으로 밨을 때 9 리터 수준에서 큰 변화는 보이 지 않고 있는 상태이다.

또한 우리나라의 1 인당 알코올 소비량을 주요 주종인 맥주, 소주, 위스키로 나누어 추 이를 살펴보았다〈그립 6 〉. 소비량은 주공협 회 출고량 및 통계청 인구통계를 기준으로 하고, 한 병당 소주는 $360 \mathrm{ml}$, 맥주 $500 \mathrm{ml}$, 위 스키 $500 \mathrm{ml}$ 를 기준으로 환산하여 계산하였 다. 그 결과 맥주와 위스키는 1998 1999년 사이에 발생한 $\mathrm{IMF}$ 시기에 소비량이 대폭 감 소하였다가, 이후에 점차 회복세를 보이고
있다. 반면 소주는 경기 상황과 상관 없이 국민주로서 1 인당 연간 70 병의 일정한 소비 추세를 보이고 있다. 따라서 상대적으로 경 기 변동에 영향을 덜 받는 '소주’ 제품과 상 대적으로 고가인 '저도주' 제품간의 적절한 제품 포트폴리오가 필요한 상황이다.

\section{7 주류 소비자 인구통계학적 분석}

두산은 주류 음용자들의 프로파일 분석을 위 해 2002년과 2003년 두 차례에 걸쳐 과거 1개 월간의 소주와 청주 음용 경험 여부에 대한 조 사를 하였다. 이를 위해 먼저 남녀 성별에 따라 소주와 청주 경험 여부를 살펴보고, 연령에 있 어서는 19 세부터 64 세까지를 5년 단위로 나누 어 살펴보았다. 그리고 성별과 연령의 조합에 따른 경험비중도 확인하였다. 
〈그림 6〉 우리나라의 주류 별 1인당 알코올 소비량

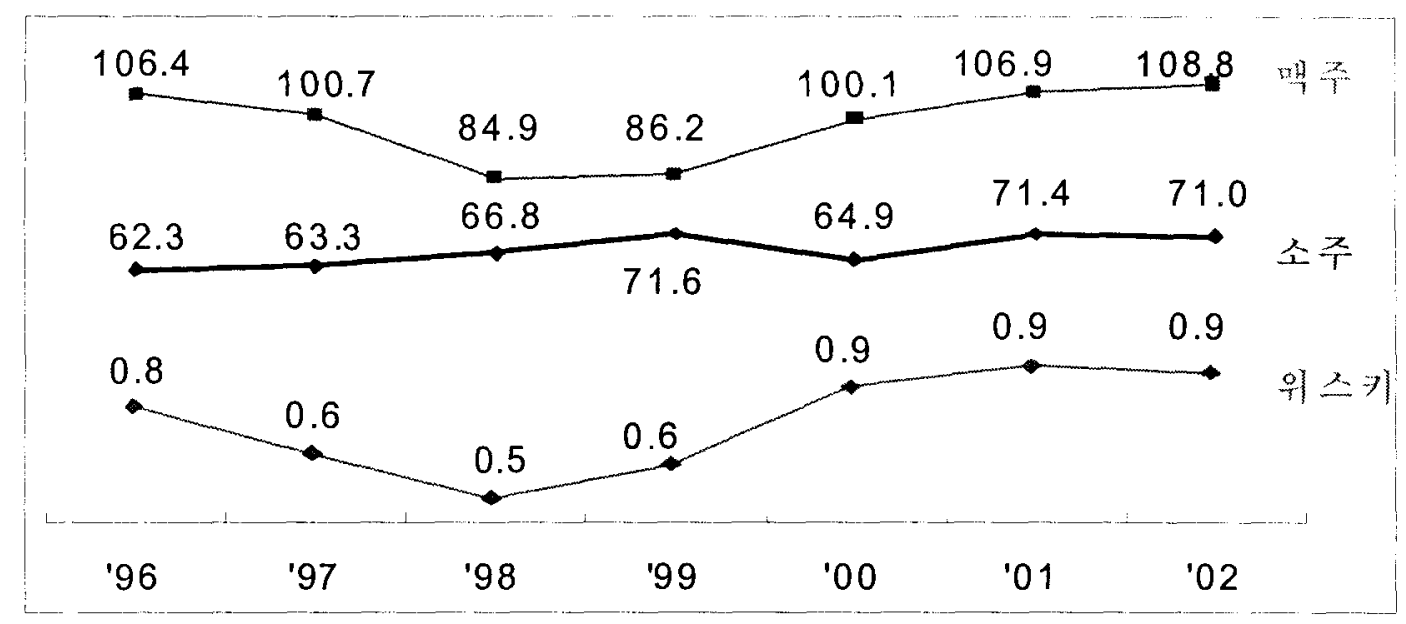

〈표 2〉 주류 소비자 인구 통계학적 분석

\begin{tabular}{|c|c|c|c|c|c|c|c|c|c|}
\hline \multicolumn{5}{|c|}{ 과거 1 개월간 소주 음용 경험자 구성비 (\%) } & \multicolumn{5}{|c|}{ 과거 1 개월간 청주 음용 경험자 구성비 $(\%)$} \\
\hline & & $\begin{array}{c}2002 \\
(\mathrm{~N}=2,294)\end{array}$ & $\begin{array}{c}2003 \\
(\mathrm{~N}=2,149)\end{array}$ & $\begin{array}{l}\text { 증감 } \\
(\% \mathrm{P} .)\end{array}$ & & & $\begin{array}{c}2002 \\
(N=49)\end{array}$ & $\begin{array}{c}2003 \\
(N=32)\end{array}$ & $\begin{array}{l}\text { 증감 } \\
\text { (\%P.) }\end{array}$ \\
\hline \multirow{2}{*}{$\begin{array}{l}\text { 성 } \\
\text { 별 }\end{array}$} & 남 & 69.9 & 66.4 & -3.5 & \multirow{2}{*}{$\begin{array}{l}\text { 성 } \\
\text { 뼐 } \\
\end{array}$} & 남 & 71.1 & 63.8 & -7.3 \\
\hline & 여 & 30.1 & 33.6 & 3.5 & & 여 & 28.9 & 36.2 & 7.3 \\
\hline \multirow{9}{*}{$\begin{array}{l}\text { 연 } \\
\text { 령 } \\
\text { 별 }\end{array}$} & $19-24$ & 17.3 & 19.8 & 2.5 & \multirow{9}{*}{$\begin{array}{l}\text { 연 } \\
\text { 령 } \\
\text { 별 }\end{array}$} & $19-24$ & 13.3 & 10.8 & -2.5 \\
\hline & $25-29$ & 13.2 & 11.3 & -1.9 & & $25-29$ & 9.9 & 10.2 & 0.3 \\
\hline & $30-34$ & 15.0 & 11.6 & -3.4 & & $30-34$ & 25.5 & 11.3 & -14.2 \\
\hline & $35-39$ & 15.5 & 15.8 & 0.3 & & $35-39$ & 16.0 & 15.2 & -0.8 \\
\hline & $40-44$ & 13.4 & 11.8 & -1.6 & & $40-44$ & 13.4 & 13.3 & -0.1 \\
\hline & $45-49$ & 11.6 & 13.6 & 2.0 & & $45-49$ & 8.1 & 12.3 & 4.2 \\
\hline & $50-54$ & 6.8 & 6.1 & -0.7 & & $50-54$ & 10.0 & 12.9 & 2.9 \\
\hline & $55-59$ & 4.4 & 5.0 & 0.6 & & $55-59$ & 3.7 & 9.2 & 5.5 \\
\hline & $60-64$ & 2.8 & 5.0 & 2.2 & & $60-64$ & 0.0 & 4.7 & 4.7 \\
\hline \multirow{8}{*}{$\begin{array}{l}\text { 성 } \\
\text { * } \\
\text { 연 } \\
\text { 령 }\end{array}$} & 남:19-29 & 19.4 & 19.5 & 0.1 & \multirow{8}{*}{$\begin{array}{l}\text { 성 } \\
\text { * } \\
\text { 연 } \\
\text { 령 }\end{array}$} & 남:19-29 & 16.2 & 10.7 & -5.5 \\
\hline & 남:30-39 & 22.5 & 19.3 & -3.2 & & 남:30-39 & 27.8 & 18.3 & -9.5 \\
\hline & 남:40-49 & 17.2 & 16.8 & -0.4 & & 남:40-49 & 16.3 & 13.8 & -2.5 \\
\hline & 남:50-64 & 10.7 & 10.9 & 0.2 & & 남:50-64 & 10.9 & 21.0 & 10.1 \\
\hline & 여:19-29 & 11.1 & 11.6 & 0.5 & & 여:19-29 & 7.0 & 10.3 & 3.3 \\
\hline & 여:30-39 & 7.9 & 8.1 & 0.2 & & 여:30-39 & 13.8 & 8.3 & -5.5 \\
\hline & 여:40-49 & 7.8 & 8.7 & 0.9 & & 여:40-49 & 5.2 & 11.8 & 6.6 \\
\hline & 여:50-64 & 3.3 & 5.1 & 1.8 & & 여:50-64 & 2.9 & 5.8 & 2.9 \\
\hline
\end{tabular}


〈표 2〉를 보면 2002년 대비 2003년 남성 음용 경험은 소주와 청주 모두에서 감소하는 것으로 나타난 반면, 여성의 음용 경험 비중은 오히려 증가한 것으로 확인되었다. 소주 음용 경험률을 연령에 따라 살펴본 결과, 25-34세의 중간 연령 층의 경험률은 줄어들고, 19 24세와 같은 상대 적 저연령층과 45 49세, $60 \sim 64$ 세와 같은 고연 령층의 음용 경험률이 다소 증가한 것으로 나 타났다. 특히 30대 남성들의 음용 경험률은 $3 \%$ 이상 하락하였으며, 50 대 이상의 여성 음용 경험률은 $2 \% \mathrm{p}$ 가량 증가한 것으로 나타났다. 청 주 음용 경험률을 연령별로 살펴본 결과, 19 44세까지의 연령층에서는 대부분 감소한 것으 로 나타났으며 특히 30대 초반인 30 34세 사 이의 경험률이 큰 폭으로 감소하였다. 하지만 오히려 45 세 이상의 연령층에서는 적게는 $3 \% \mathrm{p}$
에서 많게는 $5.5 \% \mathrm{p}$ 까지 증가한 것으로 나타났다.

\section{8 소주 소비자 행동 분석}

소주 음용에 대해 조금 더 자세하게 알아보기 위하여, 〈그립 7〉에서 연령별 인구 구성비, 월 평균 음용 빈도, 1 회 음용량, 시장 점유율 비중 에 관한 정보를 제시하였다.

위의 결과에 나타난 소주 음용자 구성비, 음 용 빈도 및 1회 음용량을 고려할 때, 20대 초반 및 30 대 후반이 가장 큰 소주 음용층인 것을 알 수 있다. 특히 20대 초반은 음용 빈도는 상 대적으로 낮지만, 1 회 음용량이 크므로, 술자리 에서 폭음을 하는 경향이 있을 것으로 예상된 다. 반면 40대 이후의 연령에서는 음용 빈도는 높지만, 1 회 음용량은 상대적으로 적은 것으로

〈그림 7〉 소주 소비자 행동 분석

\begin{tabular}{|c|c|c|c|c|}
\hline & $\begin{array}{l}\text { 연령별 인구 } \\
\text { 구성비(a) }\end{array}$ & $\begin{array}{l}\text { 월평균 음용 빈도 } \\
\text { (b) }\end{array}$ & $\begin{array}{c}\text { 1회 음용량(단위: 병) } \\
\text { (c) }\end{array}$ & $\begin{array}{c}\text { Market Size } \\
\text { 비중 }\end{array}$ \\
\hline 20 24세 & 18.5 & & & 9 \\
\hline 25 29세 & 14.4 & 5.7 & 1.06 & 12.9 \\
\hline 30-34세 & 16.2 & & & 15.5 \\
\hline 35-39세 & 16.5 & & & 5. \\
\hline 40-44세 & 14.4 & & 0.98 & 15.5 \\
\hline 45-49세 & 12.6 & & 0.94 & 13.0 \\
\hline 50-54세 & 7.4 & & 0.96 & 8.7 \\
\hline
\end{tabular}

(주) 1. 서울에 거주하는 만20 54세 월1회 이상 소주 음용자 1000 명 기준 [출처: '03년 HRC 소비자조사] 2. Market Size 비중 $\rightarrow$ 소비자의 인식상 비중임. axbxc/sum (* 제품의 판매가격 등 그 외 사항은 고려되지 않음) 
나타나고 있다.

\section{III. 〈처음처럼〉 제품 개발 과정}

\section{1 신제품 개발 주요 원칙}

두산은 신제품 개발을 위해서 다음과 같은 원 칙들을 설정하였다. 첫째, 소비자 인식에 있어 서〈참이슬〉과 철저하게 차별되어야 하며, 이를 위해서는 신제품을 마셔야 할 확실하고 신뢰할 수 있는 이유를 제시하여야 한다. 특히 코카콜 라 대 펩시콜라처럼 확실히 차별화 된 소비자 인식 구조의 형성이 필요하다. 둘째, 두산이 가 지고 있는 내부의 역량을 극대화하여야 한다. 셋째, 1 회 음용량이 많은 20 30대의 젊은 다량 음용자(heavy user)들을 공략해야 한다. 넷째, '건강', '웰빙'과 같은 요소를 통해 소주 시장의 새로운 흐름을 형성하여야 한다.

\section{2 소주 트렌드의 변화}

90년대 초반까지는 톡 쏘면서 쓴 맛을 가진 소주가 인기를 끌었고, 대표적 제품으로서 진로 가 있다. 그러다가 1994년 이후에 부드러운 맛 을 가진 소주가 인기를 얻기 시작했고, 이 때 등장한 제품이 〈그린〉이다. 1997년 이후에는 부 드러우면서도 깨꼿한 소주가 소비자의 입맛을 사로잡았고, 이 때 등장한 〈참이슬〉과〈산〉이 현재까지도 소주 시장의 대표적 제품으로 꼽히 고 있다. 하지만 시장조사결과에서도 볼 수 있 듯이 소비자의 옥구는 변화하여 왔고, 현재도
변화 중이다. 따라서 향후 소비자들이 충족 받 기 원하는 욕구는 어떠한 것이 있는지 파악하 여 이를 충족시키기 위한 마케팅 노력이 수반 되어야 한다.

\section{3 주요 트렌드 확인}

소비자들의 라이프 스타일과 트렌드 고찰을 통해서 주요 트렌드와 키워드를 도출하였다.

트렌드는 크게 건강 지향, 감성 지향, 개성 지 향의 세 가지로 구분할 수 있다. 먼저 건강 지 향 트렌드를 살펴 보면, 건강이나 자연추구 등 을 통해 인간 근본의 중요성을 인식하고, 휴식 이나 여가에 대한 관심을 통해 편안함을 추구 하며, 고령화 사회에 따라 건강에 대한 관심이 커지는 것이 주요한 특징이다.

두 번째 트렌드인 감성 지향은 시장 전반적으 로 여성적인 사고와 가치관의 비중이 커지며, 아날로그에 대해 항수를 느끼고, 기능적 요소와 함께 감성적 요소도 함께 추구한다는 것이다. 여성적인 사고는 여성 취업이 증가하고 전문직 여성이 늘어나면서 여성의 구매파워가 증가하 는 데 따른 것이며, 아날로그 향수는 디지털 세 상 속에 살면서도 디지털에 대한 비인간적인 면에 대한 거부와 아날로그의 인간적인 면에 대한 동경이 함께 작용하여 나타난 것이다. 또 한 요즘 소비자들은 기본적인 기능적 속성 이 외에 디자인이나 컬러, 향기와 같은 감성적 요. 소들이 충족되는 제품의 구매를 더욱 더 선호 하고 있다.

세 번째 트렌드인 개성 지향은 소비 형태가 다중화되고 제품가치가 변화하고 있다는 것이 주요한 톡징이다. 


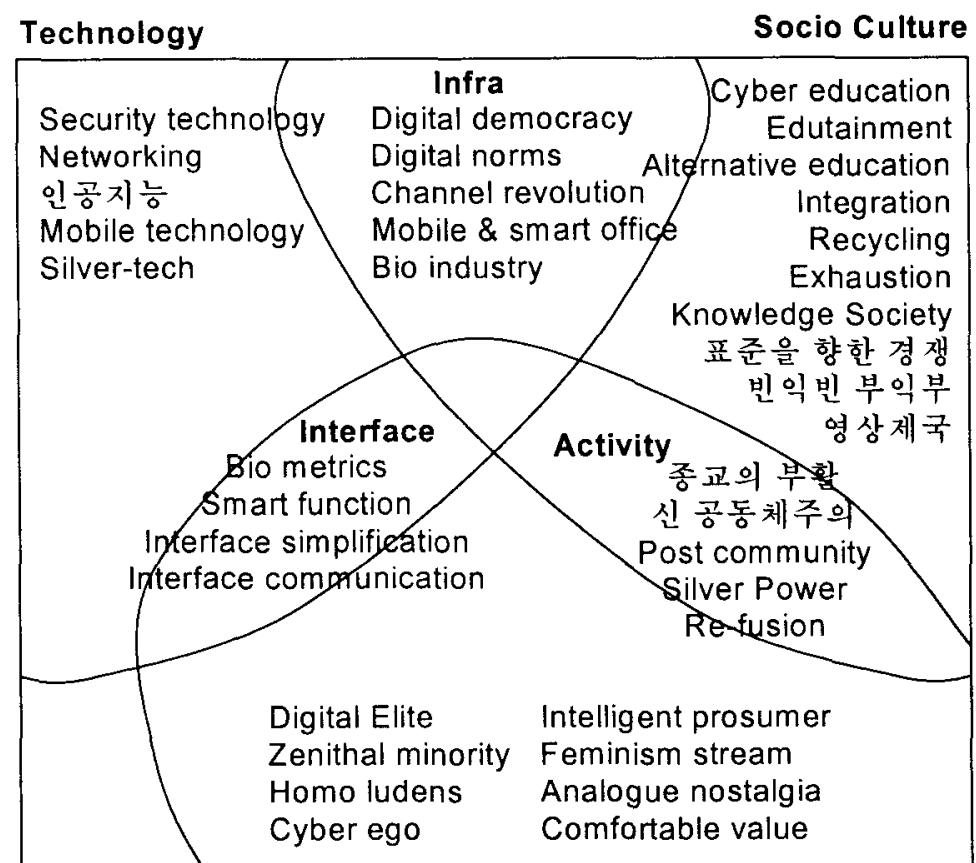

(자료원: [ 산업자원부 "Life Style동향 ] - 2001년 8월

기타: 감성마케팅 잠든 시장을 깨운다, 소비의 심리학, 욕망의 진화, 소비자 트렌드 21세기, 소비의 미래, 미래생활사전 외 10 권의 도서 및 경제 연구소의 2 차 자료 등)

\section{4 신제품 이상점(ideal point)}

신제품 개발에 있어서 가장 중요한 목표는 경 쟁 제품과 확실한 차별화 및 소주 제품이 지니 고 있는 본질적인 문제점에 대한 해결이다. 현 재 주요 트렌드와 소비자들이 원하는 소주의 이상점들을 통해 신제품이 포함해야 할 속성, 혜택, 가치를 도출하였다. 먼저, 주요 트렌드인 건강, 감성. 개성과 소비자들이 인식하는 소주 의 이상점인 숙취 감소, 부드러운 목넘김을 바 탕으로 '알칼리수로 만들어 목 넘김이 부드럽고 아침이 활기찬 웰빙 소주를 신제품 컨셉으로 도출하였다. 이를 위해 신제품은 20도의 도수,
알찰리수, 알라닌/아스파라긴을 주요 속성으로 하며, 소비자에게는 숙취 감소와 부드러운 목넘 김이라는 혜택을 제공하고, 이를 통해 소비자의 웰빙이라는 가치를 전달할 수 있게 된다.

3.5 시장 세분화

신제품 컨셉을 결정한 뒤에는 현재 소주 시장 을 세분화하고, 어떠한 시장에 진입할 것인지를 결정해야 한다. 소주 시장은 크게 음용 빈도. 구매 시 고려하는 주요 속성을 기준으로 세분 화할 수 있다. 그리고 각 시장 규모가 어느 정 도인지와 주로 구매하는 제품이 무엇인가 하는 것이 시장 선정시 고려해야 할 요소이다. 이를 
〈그림 9〉 소주 시장 세분화

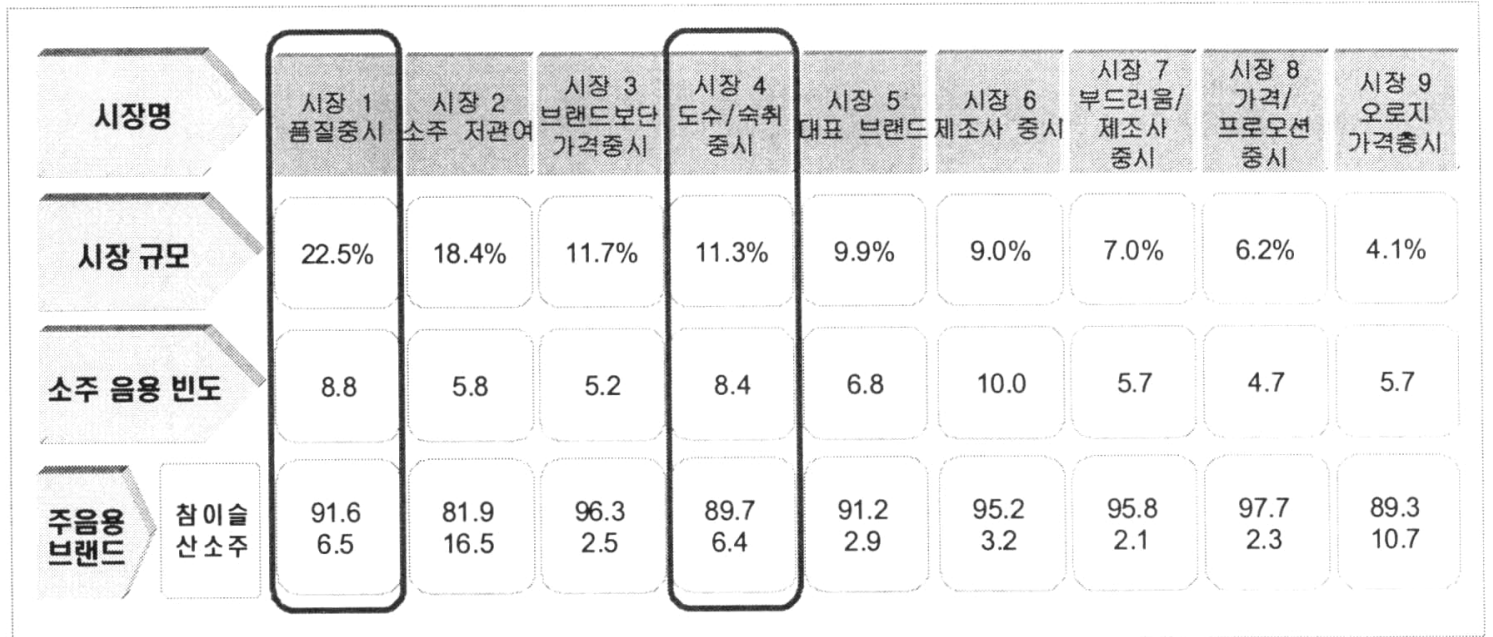

(Source: '05 U\&A 조사 결과서울/경기/강원)

종합하여 소주 시장은 크게 (1) 품질 중시 시장, (2) 소주 저관여 시장, (3) 브랜드보다 가격 중시 시장, (4) 도수/숙취 시장, (5) 대표 브랜드 시장, (6) 제조사 중시 시장, (7) 부드러움/제조사 중시 시장, (8) 가격/프로모션 중시 시장. (9) 오로지 가격 중시 시장으로 구분할 수 있다.

여기에서 신제품 컨셉에 부합하면서 매출 확 보를 위해 시장 규모와 음용 빈도가 높은 대량 음용자(heavy user)를 공략해야 한다. 따라서 품질을 중시하는 시장과 도수 및 숙취를 중시 하는 시장 에 진입하기로 결정하였다.

\section{6 소주에 대한 불만족 욕구와 대안 탐색}

현재 소비자들이 소주에 대해 가지고 있는 주 요 불만족 사항과 이를 위한 대안은 어떠한 것 이 있는지 살펴보고, 이를 신제품 개발 과정에 반영하여야 한다. 소비자들을 대상으로 조사한 결과 소주에 대한 가장 큰 불만족은 심한 알코
올 냄새와 음주 후의 숙취 현상인 것으로 나타 났다. 특히 숙취는 소주가 건강에 해롭다고 생 각하는 소비자 인식의 핵심 근거로서 이에 대 한 직접적인 대안이 필요한 상황이다. 숙취를 완화하는 것은 건강에 덜 해롭다는 인식 형성 에 영향을 주기 때문에 이를 위한 구체적인 방 안들을 고려해야 한다. 도수를 낮추는 방법, 첨 가물을 사용하는 방법, 기능성 물을 사용하는 방법 등 크게 세 가지 방안을 고려할 수 있다. 첫째 도수를 낮추는 방법에 있어서는 찬반의견 이 분분하지만, 최소한 도수를 낮추는 것이 숙 취를 완화시키는데 도움을 준다고 소비자들은 인식하고 있다. 둘째, 첨가물을 사용하는 방법 은 현재까지 출시된 유사한 제품들의 효과는 미미했지만, 향후 혁신적인 첨가물을 사용한다 면 숙취 완화 효과를 기대해 볼 수 있다. 마지 막으로 기능성 물을 사용하는 것은 음주 후 마 시는 물이 숙취개선에 효과가 있다는 측면에서 소주 제조에 사용되는 물 자체를 개선하면 숙 
취를 완화할 가능성을 찾아볼 수 있다.

\section{7 소주의 주원료-물}

소주는 $79 \%$ 의 물과 $20 \%$ 의 알코올, 그리고 $1 \%$ 의 첨가물로 구성되어 있다. 따라서 소주의 맛과 품질을 좌우하는 가장 중요한 요소는 $80 \%$ 를 차지하는 물인 것이다.

음용수 기준을 바탕으로 광천수, 죽탄수, 옥정 수, 지장수, 황토수, 육각수, 정화수 등 많은 물 을 연구했지만, 실제 좋은 물이 되려면 (1) 유 해물질이 없고, (2) 미네랄이 풍부하며, (3) 약 알칼리성을 띄고, (4) 육각수에 가까우며, (5) 항 산화 작용을 해야 하는 것으로 나타났다 (KBS 1, 생로병사의 비밀). 이러한 5 가지 좋은 물의 요건을 완벽하게 충족시켜주는 물이 바로 '알칼리 환원수'이며, 알칼리 환원수의 효과는 이미 많은 언론에서 소개된 바 있다(KBS 생로 병사 '알칼리환원수' 소개, $\mathrm{MBC}$ 특집 '생명수의 진실', $\mathrm{SBS}$ 아는 것이 힘이다, $\mathrm{SBS}$ 신 건강상 식, KBS 특집 '물이 암 예방' 등).

알칼리수는 물 입자가 작고, $\mathrm{pH} 8.3 \sim \mathrm{pH} 8.5$ 를 유지하며, 미네랄과 활성 수소가 풍부한 것
이 특징이다. 이러한 알칼리수는 목넘김이 부드 럽고, 산성 체질을 중화시켜주며, 알코올 분해 활동을 촉진시키고, 활성 산소를 제거하는 것과 동시에 노화를 방지하는 작용을 한다. 만약 알 칼리수를 원료로 소주를 만든다면 맛이 부드럽 고, 산성 안주를 중화시키며, 신체 균형을 환원 시키면서 숙취를 해소하게 될 것이다. 이와 같 은 알칼리수 소주에 대한 효과를 좀 더 구체적 으로 살펴보도록 하자.

첫째, 알칼리수의 주요한 역할 중 하나로 알 칼리수의 산성 중화 작용 효과를 예상할 수 있 다. 소주 안주는 크게 찌게와 고기로 구분할 수 있다. 찌게에는 감자탕, 알탕, 동태찌개 등이 대 표적이고, 고기는 회, 삼겸살, 소고기 등이 대표 적 제품이다. 이 때 소주와 먹는 안주들은 대부 분 $\mathrm{pH}$ 5.7 7.1의 약산성을 띄고 있다. 이 때 알칼리수로 만든 소주를 마신다면 이와 같은 안주들의 체내 산성작용을 중화시키는데 도움 이 될 것이다.

둘째, 알칼리수는 활성 산소 제거에 효과가 있다. 알칼리수는 자연수/수돗물 $\rightarrow$ 필터링 시 스템 $\rightarrow$ 살균 시스템-(정수) $\rightarrow$ 전기 분해를 통 해 알칼리 환원수와 산성수로 구분되는데, 양극

〈그림 10〉 소주의 구성 성분

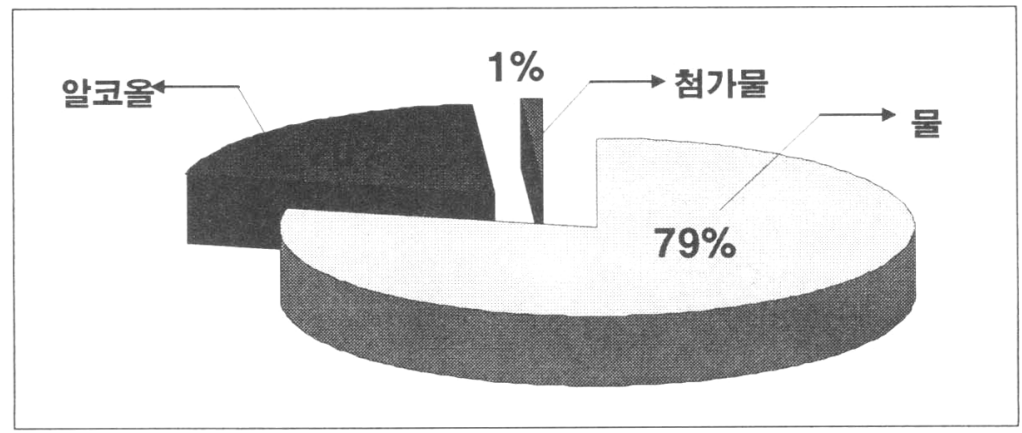


측에 해당하는 산성수는 신체 노화를 촉진시키 는 반면, 음극측에 해당하는 알칼리 환원수 활 성 산소를 제거해주는 활성 수소를 지니고 있 다. 특히 산성지수가 높고, 산화환원지수(ORP) 수치가 낮을수록 환원력이 높은데. 환원력이 높 을수록 산성 체질 중화 및 신체 균형 유지를 통한 노화 방지에 대한 효과가 뛰어나다. 따라 서 알칼리수로 만든 소주는 활성산소를 제거하 여 산성화를 약화시키면서, 신체 노화를 방지하 는 역할을 할 것이다.

셋째, 알칼리수는 매우 작은 물 입자를 지니 고 있다. 일반적으로 보통의 물은 $10 \sim 13$ 개의 물분자 구조가 모여 형성된 반면, 알칼리 환원 수는 6 개, 즉 육각형 형태로 보통 물 구조 크기 의 절반에 가깝다. 이러한 미세한 물 구조는 인
체 내 흡수와 배출이 빠르기 때문에 술 맛에 있어 숙성감을 더해 준다.

넷째, 알칼리수는 풍부한 미네랄을 함유하고 있다. 미네랄은 단백질, 지방, 탄수화물, 비타민 과 더불어 인체에 꼭 필요한 5 대 필수 영양소 중의 하나로 체중의 약 $4 \%$ 를 차지하고 있다. 미네랄은 주로 체내 물의 균형을 조절하고, 적 정한 $\mathrm{pH}$ 농도를 유지하며, 독성 물질을 해독하 고, 세포의 자율신경을 보조하며, 분해를 촉진 하는 기능을 한다. 사람이 알코올을 대사하는 과정 중에서 알코올 탈수소효소(ADH) 수치가 낮아지는데, 이 때 $\mathrm{ADH}$ 수치를 자동조절하기 위해 인체 내 다른 부위에서 미네랄을 가져오 게 되며, 이 과정에서 숙취의 대표적인 현상인 두통과 매스꺼움, 무기력 등이 발생하게 된다.

\section{〈그림 11〉 알칼리수 제조 공정}

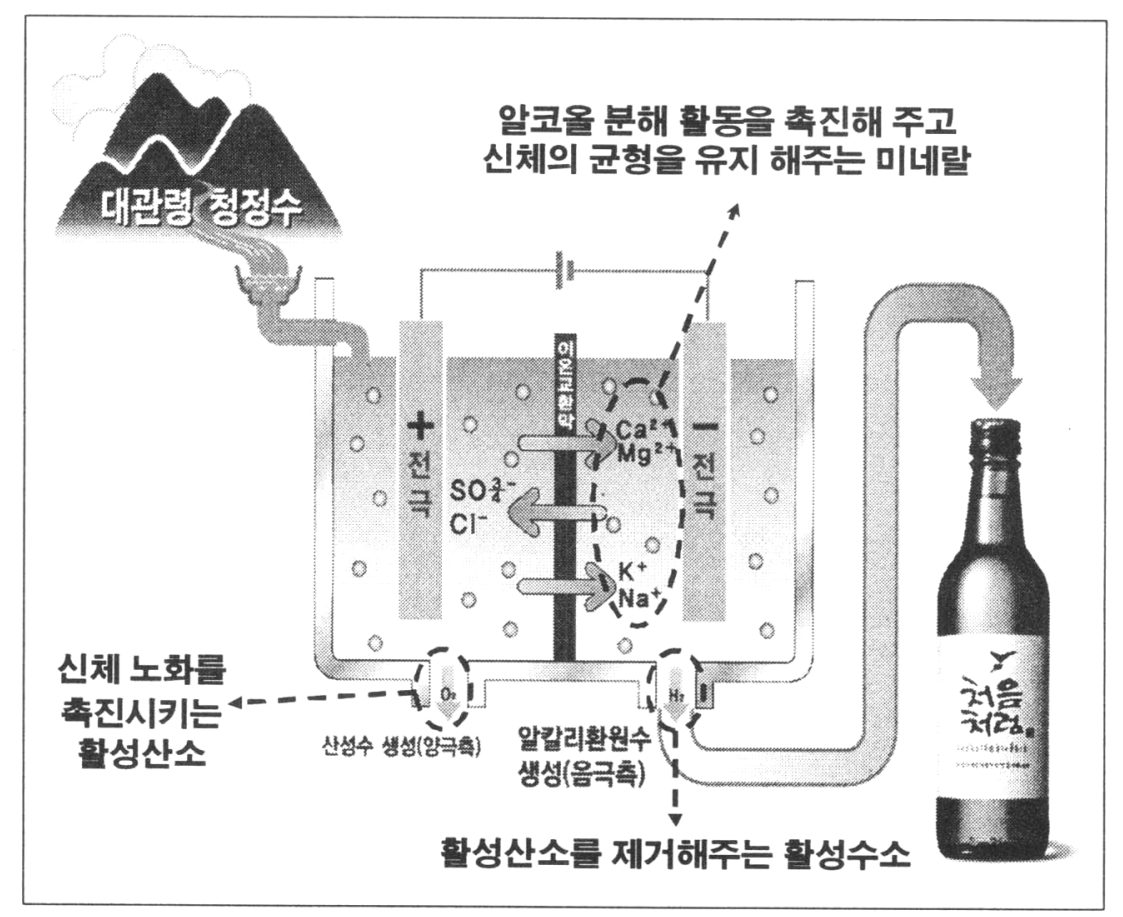


클러스터가 큰 물

(통과하지 못함)

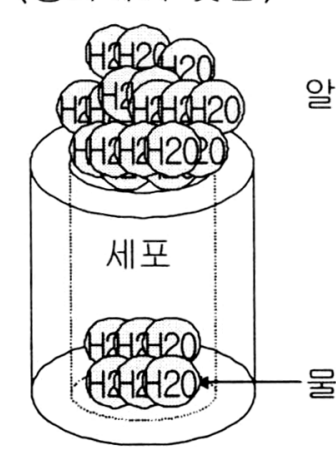

클러스터가 작은 물

(통과함)

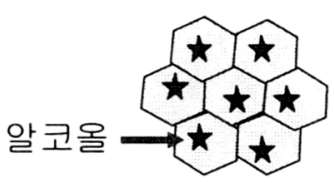

환원수 구조

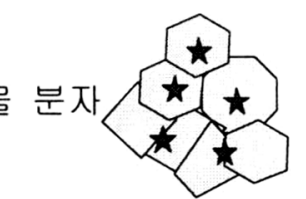

일반수 구조

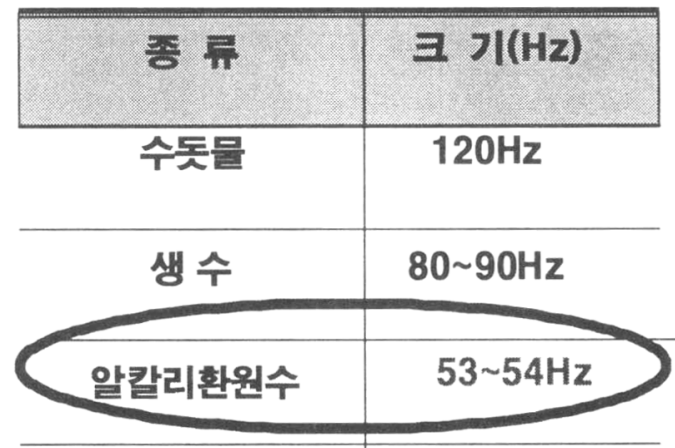

인체 세포
$58 \sim 60 \mathrm{~Hz}$

\section{(클러스트 비교)}

따라서 알칼리수는 풍부한 자연 미네랄로 인해 음주 후 $\mathrm{ADH}$ 의 자동 조절을 도와 숙취를 해 소하는 데 기여하게 된다. 결국 소비자들의 주 요 불만 사항인 숙취 문제를 위해서는 알칼리 수를 소주 원료로 사용하는 것이 가장 적합하 다는 결론이 도출된다

이뿐만 아니라, 숙취 해소를 위해 신제품에는 북어국에 많이 들어있는 알라닌과 아스파라긴 을 첨가하고, 소주 맛을 풍부하도록 하기 위해 최고급 스테비오 사이드를 사용하며, 자일리톨 성분을 포함하도록 하였다.

\section{8 신제품 개발과정}

신제품 개발은 1 년 6 개월에 걸쳐 이루어졌으 며, 이 동안 4.650 명의 소비자를 대상으로 총 31회의 시장조사를 실시하였다. 구체적으로 살 펴보면, 제품 컨셉 테스트를 위해 1,000 명의 소
비자를 대상으로 3 회의 조사가 이루어졌고, 최 상의 맛을 위해 2,200 명의 소비자를 대상으로 22회의 조사가 이루어졌다. 또한 제품명과 패키 지 디자인을 위해 450 명을 대상으로 3 번의 조 사를 실시하였으며, 제품 포지셔닝을 위해 3 회 에 걸쳐 1,000 명의 소비자를 대상으로 조사하였 다. 이를 통해 브랜드 아이덴티티를 개발하였는 데, 전체적으로 모던하고 심플한 디자인을 바탕 으로 깔끔한 미색과 심플함으로 소주의 순수함 을 반영하고, 수기체의 제품명을 통해 안정감을 표현하였다. 〈처음처럼〉이라는 이름은 술을 마 신 다음 날에도 몸 상태가 원래대로 환원된다 는 의미를 지니고 있으며, 이를 위해 처음 돋아 나는 새싹 이미지를 제품명 아래에 삽입하고, 맨 처음 기쁜 소식을 전해주는 까치를 제품명 위에 배치하였다. 
〈그림 13〉 브랜드 개발

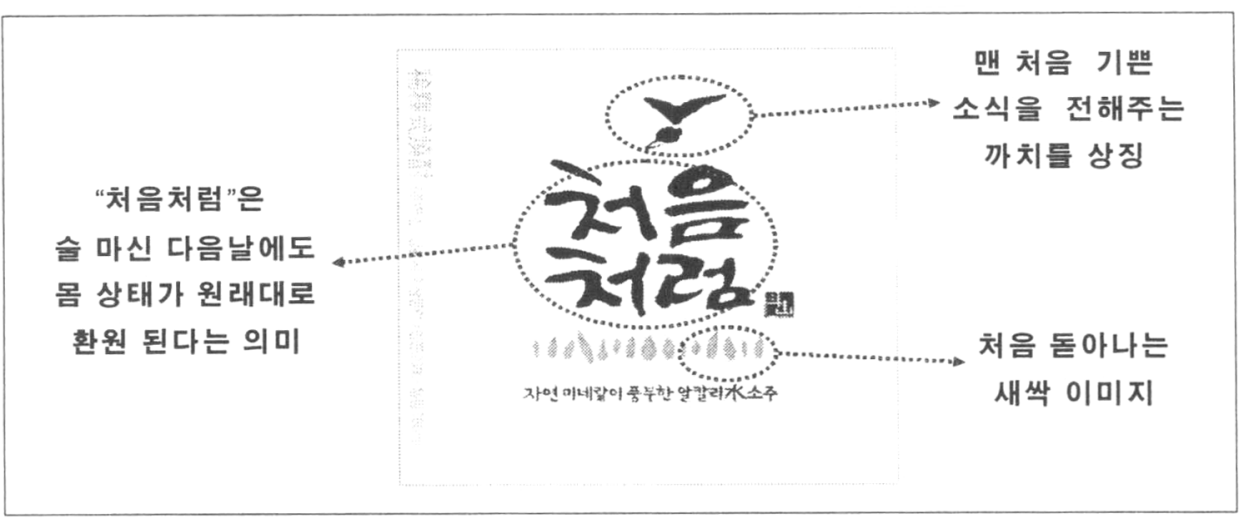

3.9 주요 속성별 상대적 선호도

제품의 주요 요소들이 결정되고 난 뒤에 전반 적 호감도, 부드러움, 깨끗함, 알코올취, 소주 맛, 구매 의향, 선호도와 같은 주요 속성에 대 해〈처음처럼〉과 경쟁 제품에 대한 소비자 선
호도 조사를 실시하였다.

결과에서 알 수 있듯이 〈처음처럼〉은 모든 주 요 속성에서 경쟁 제품에 비해 높은 선호도 점 수를 받았으며, 특히 전반적인 호감도와 소주 맛, 선호도에서 경쟁 제품과의 격차가 더욱 크 게 나타나는 것을 알 수 있다.

〈그림 14〉 주요 속성별 상대적 선호도 조사

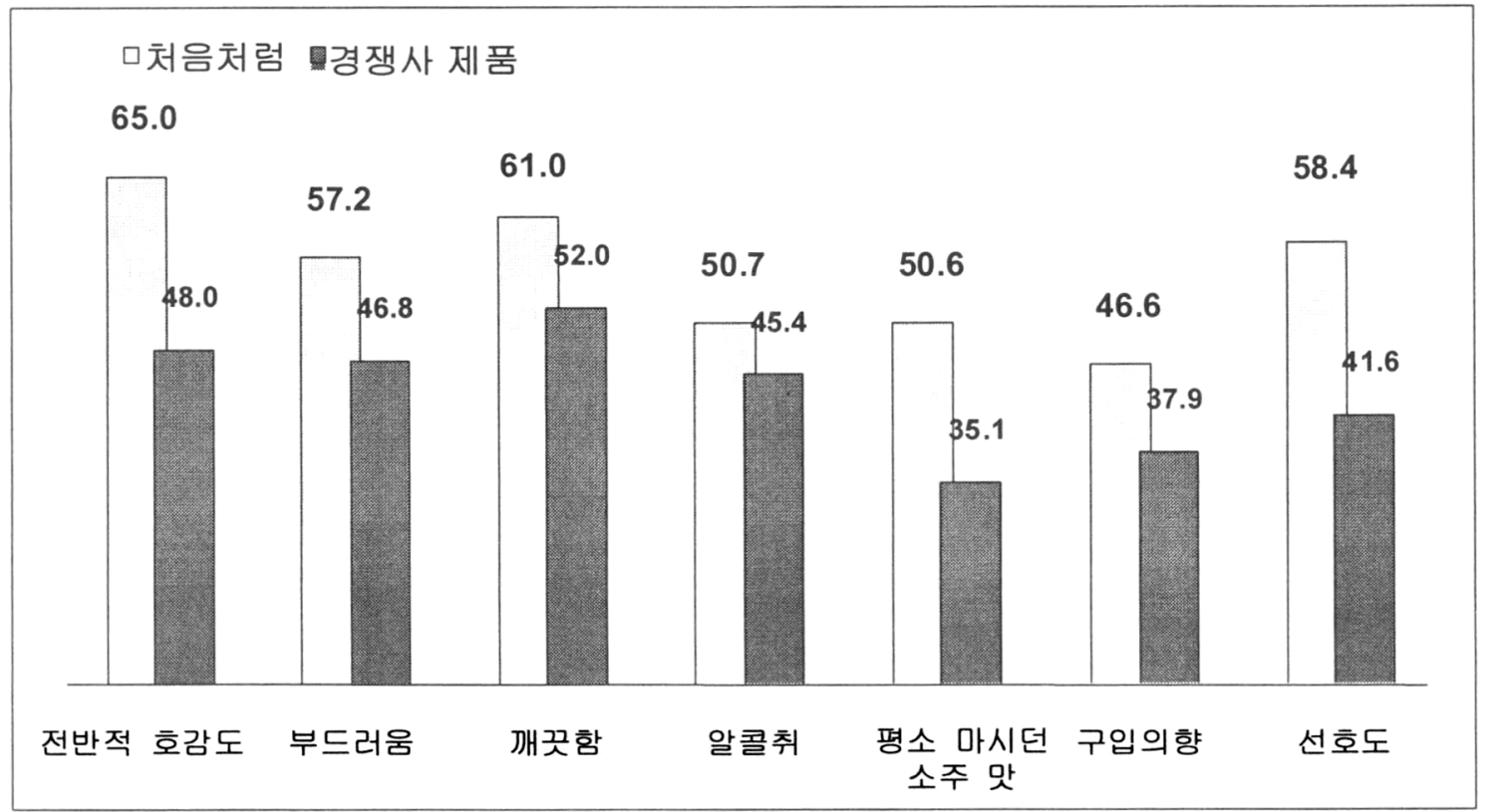




\section{IV.〈처음처럼〉의 마케팅 전략}

\section{1 브랜드 전략}

여기에서는 〈처음처럼〉 브랜드가 지니고 있는 여러 가지 이슈들과 전략에 대해 살펴보고자 한다. 먼저 두산에서는 〈참이슬〉의 소주시장 독 주에 대한 대응이 필요하지만, 기존 제품인 〈산〉소주의 성장 한계를 인식함으로 인해 건강, 자연, 웰빙 트렌드에 부합하는 신개념의 소주를 개발할 필요성이 있었다. 이 때 내부적으로는 〈참이슬〉 독주를 막고 시장 점유율 $20 \%$ 이상을 달성하여 소주 시장의 새로운 대표주자가 된다 는 비전을 지니고 있었고, 외부적으로는 부드러 운 맛과 부담 없는 가격을 통해 즐겁고 편안한 소주문화를 제공한다는 비전을 가지고 있었다. 이러한 내/외부적 비전을 통해 소주 시장의 새
로운 패러다임을 창출하는 것이〈처음처럼〉브 랜드의 비전인 것이다.

〈처음처럼〉의 브랜드 아이덴티터는 크게 기능 적 혜택, 감성적 혜택, 자기표현적 혜택으로 구 분할 수 있다. 기능적 혜택(functional benefit) 에서는 '몸에 잘 받는, 산성음식과 잘 어울리는, 부담 없는 뒤 끝을 주요 가치로 제공하고, 감 성적 혜택(emotional benefit)에서는 '새롭고 신 선한 느낌. 편안하고 즐거움을 주는'이라는 가 치를 제공하며, 자기표현적 혜택 (self-expressive benefit)에서는 '세련된 웰빙 라이프 스타일'을 주요 가치로 제공하고 있다. 이를 통해 고객에 게 '편안하고 건강한 즐거움을 주는 생활 동반 자'로서의 관계를 지향하고 있다.

\section{$4.24 \mathrm{P}$ 전략 방향}

〈처음처럼〉의 기본적인 마케팅 전략은 다음과

〈그림 15〉 브랜드 아이덴티티 체계

\section{Value Proposition}

Functional benefit

Emotional benefit

Self-expressive benefit

- 몸에 잘 받는

- 산성음식과 잘 어울리는

- 부담 없는 뒤 끝
- 새롭고 신선한 느낌

- 편안하고 즐거움을 주는
- 세련된 Well-being Life Style

\section{Brand-Customer Relationship}

\section{편안하고 건강한 즐거움을 주는 생활동반자}


같다. 먼저, 마케팅 및 영업 활동을 24 35세대 에 집중하여 공략한다. 그리고 유흥업소가 밀집 한 중심상권을 집중적으로 공략한 후에 가정 시장으로 확대하도록 한다. 그 다음 〈참이슬〉에 대비한 저가정책을 통하여 유통 채널 마진을 극대화함으로써 신제품 확산의 명분을 제공하 고, 소비자 가계의 부담을 축소하도록 한다. 마 지막으로 목표 고객의 인지도 제고와 더불어 제품 시용 유도를 위해 차별화된 소비자 캠페 인 및 새로운 미디어를 적극적으로 활용하도록 한다. 이와 같은 마케팅 전략들은 특정 대상을 집중적으로 공략한 후에 이를 발판으로 삼아 시장을 확대시킨다는 기본 방침을 공통적으로 지니고 있다.

\section{3 광고 전략}

광고는 크게 4단계로 구분하여 전락을 사용하 였다. 먼저 1 단계에서는 $\mathrm{pH} 8.3$ 의 알칼리수, 풍 부한 미네랄, 작은 물 입자 등과 같이 제품이 지닌 주요 특징들에 대해 알리고, 세계최초 알
칼리수 소주가 탄생했음을 소비자들에게 인식 시켜야 한다. 이를 위해 $\mathrm{PR}$ 성 광고를 활용한다. 2단계에서는 '부드러운 목넘김, 산성 음식 중 화, 빠른 숙취 해소 등과 같은 기능적 가치를 강조하고, 고객이 차별성과 신뢰성을 인식하도 록 한다. 이를 위해 합리적이면서 재미있는 광 고를 사용한다.

3 단계에서는 '새롭고 신선함, 몸이 편안함, 술 자리가 즐거움 등과 같은 정서적 가치를 강조 하며, 이를 통해 〈처음처럼>이 내 브랜드라고 인식하는 충성 고객을 확대시켜 정서적 연대감 형성을 목표로 한다. 이를 위해 소비자의 정서 를 자극하는 감성적 광고 형태를 사용하도록 한다.

4단계에서는 '세련된 웰빙 라이프'를 통한 사 회적/생활 가치를 제공하고, 새로운 음주 문화 를 선도하면서 친밀한 유행브랜드로 자리 잡아 소비자의 생활 속의 브랜드로 인식되도록 한다. 이 단계에서는 TV 방송이나 광고 같은 것들이 실제 생활세계의 일부분을 나타내고 있다는 것 을 의미하는 slice of life형태의 광고를 제작하

〈표 3〉단계별 광고 전략

\begin{tabular}{|c|c|c|c|}
\hline 1단계 & 2단계 & 3단계 & 4단계 \\
\hline $\begin{array}{l}\text {-사실/특성 } \\
\text { - pH8.3의 알칼리수 } \\
\text { - 풍부한 미네랄 } \\
\text { - 작은 물 입자 } \\
\text {-제품 탄생 고지 } \\
\text { - 세계최초알칼리수소주 } \\
\text { - 새로운 카테고리 소주 } \\
\text {-PR성 광고 }\end{array}$ & $\begin{array}{l}\text { •기능가치 } \\
\text { - 부드러운 목 넘김 } \\
\text { - 산성음식 중화 } \\
\text { - 빠른 숙취 해소 } \\
\text {-제품 편익 소구 } \\
\text { - 우월한 차별성 } \\
\text { - 신뢰성/납득성 } \\
\text {-Rational+Fun 광고 }\end{array}$ & $\begin{array}{l}\text {-정서가치 } \\
\text { - 새롭고 신선함 } \\
\text { - 몸이 편안함 } \\
\text { - 술자리가 즐거움 } \\
\text {-감성적 연대감 } \\
\text { - 마이 브랜드 } \\
\text { - 충성고객 확대 } \\
\text {-Emotional 광고 }\end{array}$ & $\begin{array}{l}\text {-사회/생활가치 } \\
\text { - 세련된 웰빙 라이프 } \\
\text {-생활 속의 브랜드 } \\
\text { - 새로운 음주 문화 } \\
\text { - 친밀한 유행 브랜드 } \\
\text {-Slice of Life 광고 }\end{array}$ \\
\hline 제품 속성 고지 & 제품 대세론 & & 세세론 \\
\hline
\end{tabular}


도록 한다.

\section{4 가격 전략}

〈처음처럼〉은 경쟁사인 〈참이슬〉에 대비하여 상대적으로 저가로 진입하는 시장침투 가격전 략을 사용하였다. 먼저 유흥용 제품을 살펴보 면, 〈참이슬〉의 출고 가격이 24,000 원인데 반해 〈처음처럼〉은 2,100원 저렴한 21,900원으로 책 정하였고, 1차 유통업체에서 〈참이슬〉 마진이 6000 원인 것에 반해 〈처음처럼〉은 1,100 원 높은 7,100 원의 마진을 남길 수 있도록 하였다. 가정 용 제품의 경우에는 〈참이슬〉이 24,000 원인데 반해, 〈처음처럼〉은 21,900 원으로 2,100 원이나 저렴하게 책정하였으며, 그 결과〈참이슬〉의 1 차 유통업체 마진이 1,200 원인데 반해 〈처음처 럼>은 600 원 높은 1,800 원의 마진이 발생하였 다. 이처럼 〈참이슬〉에 비해 상대적으로 낮은 가격은 유통업체들의 높은 마진을 보장해주기 때문에 신제품 취급 동기를 강화할 수 있었다.

\section{5 촉진 전략}

〈처음처럼〉은 부드러운 목넘감과 숙취 예방이 주요 강점인 만큼 소비자들이 이를 실제로 경 험하도록 하는 것이 매우 중요하다. 따라서 두 산은 샘플 지급을 통한 대대적인 촉진 전략을 시행하였다. 1차 유통업체에 있는 직원 9,600명 전원, 2 차 유통업체인 업소( 60.000 개)와 가정 (18,000개), 의견 선도자 76,000 명, 일반 소비자 $1,330,000$ 명. 그룹사 6,000 명 등 총 150 만 명의 소비자에게 샘플을 지급하였다.

또한, '처음돌이'를 마스코트로 내세워 주요
지점에서 카퍼레이드, 지하철 순회, 꼭지점 댄 스, 즐거운 선택 등 다양한 캠페인을 실시하였 다. 그리고 실제 구매가 이루어지는 곳을 찾아 가 다양한 접점 이벤트로 실시하기 위해, 유흥 시장에서는 즉석 스크래치 카드나 펀 \& 펀 배 틀 등과 같은 이벤트를 실시하고, 가정 시장에 대해서는 매장 내 주요 장소에 제품을 다량 전 시하도록 하였다. 이와 같은 다양한 이벤트와 행사는 소비자들에게 〈처음처럼〉 이라는 브랜 드를 인식시키는 동시에 브랜드에 대한 호기심 을 불러일으켜 구매 욕구를 증가시켰다.

\section{V. 시장 성과}

\section{1 시장 점유율 변화}

전국과 수도권에서의 〈처음처럼〉의 시장점유 율 증가추이를 나타내고 있는 〈그림 16)과〈그 림 17〉을 보면, 〈처음처럼>이 소주 시장에 출시 된 후 1 년간 시장 점유율이 빠른 속도로 증가 하고 있음을 알 수 있다(대한 주류 공업 협회 자료).

이들 그래프에서 나타나듯이 〈처음처럼〉의 시 장 점유율은 수도권 및 전국 지역에서 모두 증 가하고 있다. 2006년 1월에 6.4\%였던 수도권 점유율이 11 월에는 $19 \%$ 까지 증가하였고, 전국 점유율 역시 $5.2 \%$ 에서 $10.9 \%$ 로 증가하였다. 특 히 〈참이슬〉이라는 독보적 경쟁자가 있는데도 불구하고 단기간에 이처럼 시장 점유율이 증가 한 것은 보기 드문 사례로, 현재까지는 매우 성 공적으로 시장에 진입하였음을 알 수 있다. 
〈그림 16〉시장 점유율 변화전국

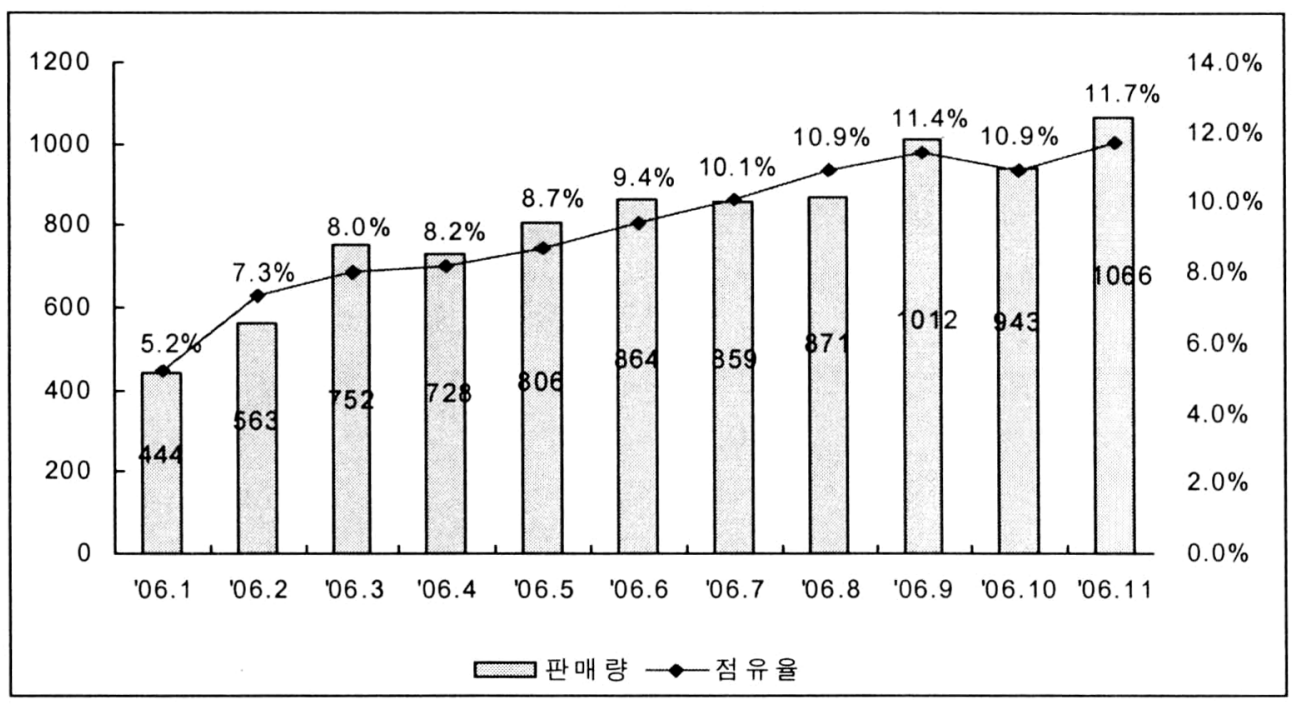

〈그림 17〉시장 점유율 변화수도권

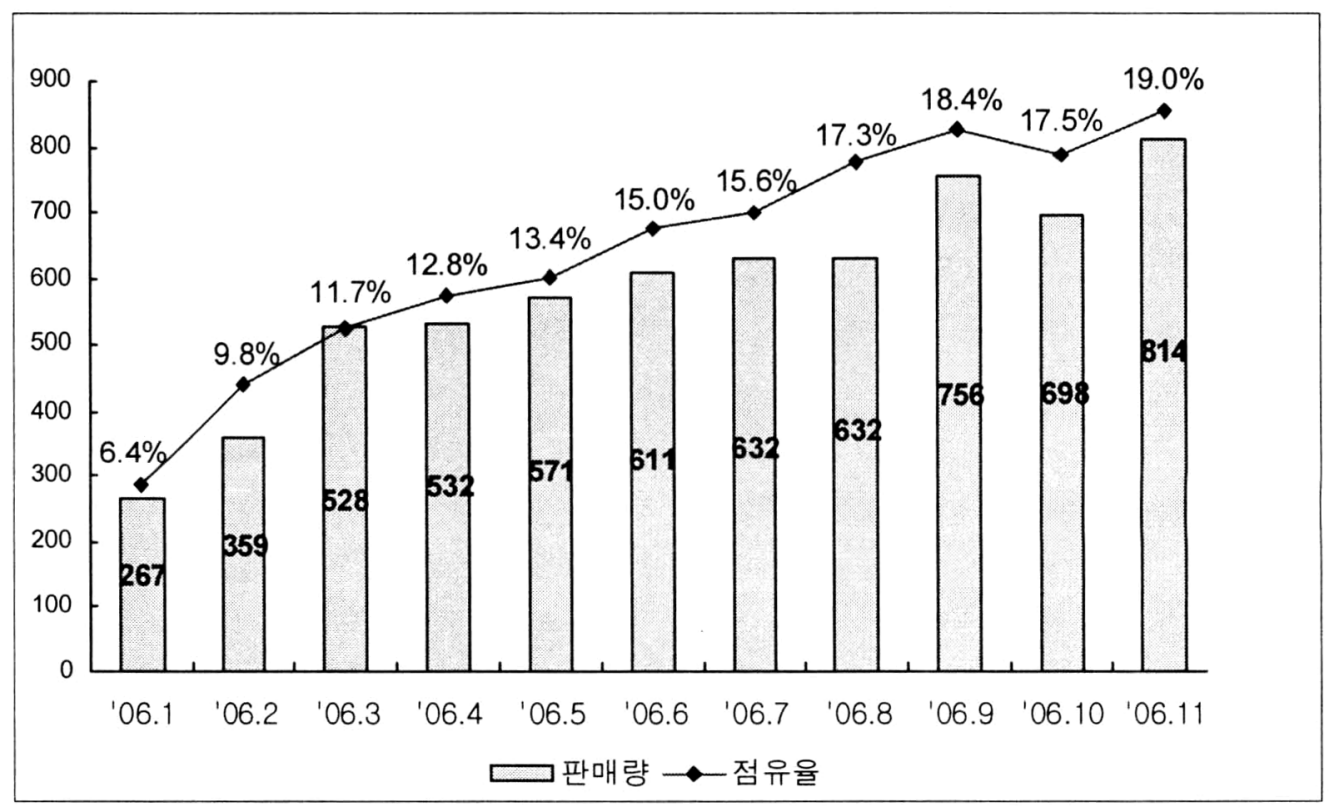

5.2 브랜드 별 이미지 조사

〈처음처럼〉은 경쟁 제품인 〈참이슬〉과의 확실
한 차별화를 주요한 목표로 설정하며 출시되었 다. 제품 출시 후 이에 대한 소비자의 반응을 확인하기 위해〈처음처럼〉과〈참이슬〉에 대한 
소비자 조사를 실시하였다. 조사 결과 〈처음처 럼〉은 '순다', '부드럽다', '알칼리수'의 이미지로 주로 소비자에게 인식되고 있었으며, 〈참이슬〉 은 '깨끗하다', '전통있다/오래됐다', '대중적이다' 의 이미지로 인식되고 있다. 따라서 소비자가 인식하는 두 제품간의 이미지는 〈처음처럼〉이 의도한 것처럼 확연히 다르게 인식하고 있음을 알 수 있다. 이와 같은 두 제품간의 이미지 차 이는 〈표 4〉에서 확인할 수 있다.

\section{3 성공 요인}

〈처음처럼〉이 이처럼 소주 시장에서 성공을 거둘 수 있었던 이유는 4가지 요인으로 압출해 볼 수 있다. (1)알칼리 환원수. (2)감성적 브랜 드명, (3)차별화된 마케팅 전략, 그리고 (4) 전 조직원의 강력한 성공 의지, 이들 4 가지 요인들 이 지금의 〈처음처럼〉을 만들어낸 것이다.
첫째, 알칼리 환원수를 사용하여 목 넘김이 부드럽고 숙취가 적다는 점에서 뛰어난 제품력 을 지니고 있다. 이러한 기능들은 건강을 중시 하는 웰빙 트렌드와 부합하여 더욱 큰 반항을 불러일으켰다.

둘째, 감성적인 브랜드명의 사용이다. 감성을 중시하는 소비자의 라이프 스타일에 부합하고 제품의 특징을 잘 나타내는 브랜드명을 개발함 으로써 시너지 효과가 발생하였다.

셋째, 차별화된 마케팅 전략이다. 〈처음처럼〉 은 기존주류업체와는 차별화된 다양한 마케팅 활동을 전개하였다. 이러한 마케팅 전략은 단기 간에 소비자에게 제뚬을 알리고 인지도를 제고 시키는 데 주요한 역할을 하였다.

마지막으로 성공을 향한 전 조직원의 강력한 의지이다. 두산이 소주 시장에 진입한지는 오래 되었지만, 시장 점유율 $5 \%$ 내외로 1 위인 <참이 슬>과는 비교도 되지 않는 위치에 처해 있었다.

〈표 4〉〈처음처럼〉과〈참이슬〉 이미지 조사 결과

\begin{tabular}{|l|l|l|c|}
\hline \multicolumn{2}{|c|}{ 〈처음처럽〉 } & \multicolumn{2}{c|}{ 〈참이슬〉 } \\
\hline BASE FOR \% & 1100 & BASE FOR \% & 1100 \\
\hline 순하다 & 18.4 & 깨끗하다 & 10.1 \\
\hline 부드럽다 & 9.7 & 전통있다/오래됐다 & 9.5 \\
\hline 알칼리수 & 9.6 & 대중적이다 & 7.0 \\
\hline 깨끗하다 & 8.5 & 친근하다 & 5.4 \\
\hline 새롭다 & 6.5 & 두꺼비 & 3.9 \\
\hline 도수가 낮다 & 6.5 & 맑다 & 3.8 \\
\hline 맛이 순하다 & 5.2 & 부드럽다 & 3.5 \\
\hline 신선하다 & 5.1 & 목 넘김이 부드럽다 & 3.5 \\
\hline 맛이 싱겁다 & 4.5 & 우리나라 대표 소주 & 3.3 \\
\hline 맛이 부드럽다 & 3.0 & 깔끔하다 & 3.1 \\
\hline 목 넘김이 부드럽다 & 2.5 & 진로 & 2.8 \\
\hline
\end{tabular}


〈그림 18〉〈처음처럼〉과〈참이슬〉의 포지셔닝맵

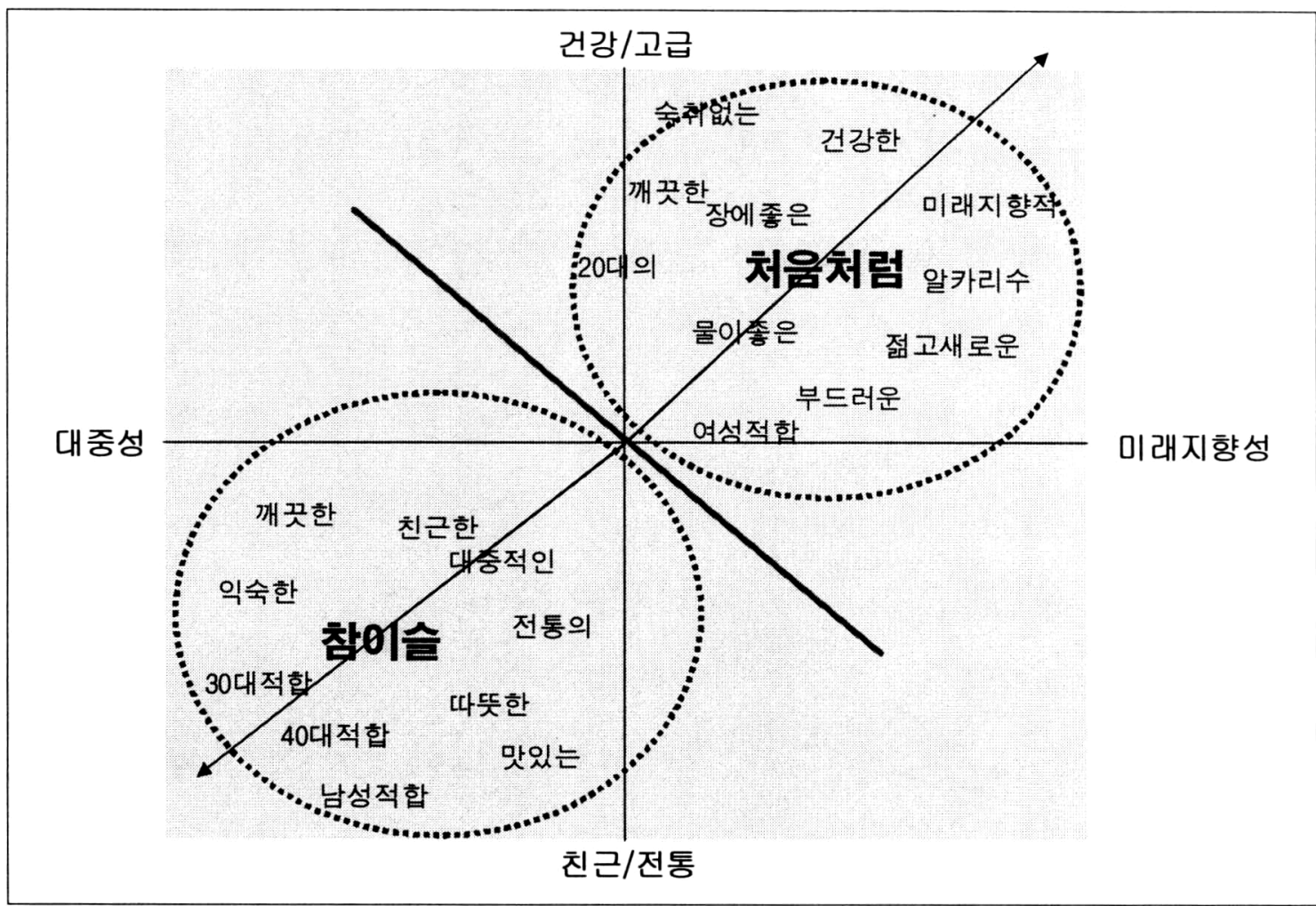

(Multiple Correspondence Analysis)

따라서 이번 제품만은 소중 시장에서 꼭 성공 하고 말겠다는 조직원들의 강력한 열망이 신제

VI. 향후 과제와 전략 방향 품에 대해 끝없이 고민하고 노력하게 만들었다.

이처럼〈처음처럼〉은 다양한 노력들을 통해 성공할 수 있었으며, 이는 주류 업계뿐만 아니 라 신제품을 개발하려는 다른 기업들에게도 좋 은 사례가 될 수 있을 것이다. 특히 참이슬〉과 같이 독보적인 우위를 차지하는 기업에 대항하 여, 경쟁력있는 신제품 개발을 고민하는 많은 기업들에게 도움을 주리라 기대된다.

현재〈처음처럼〉은 소주 시장에서 괄목할 만 한 성과를 거두었지만, 앞으로 극복해야 할 과 제들이 있다. 여기에서는 〈처음처럼〉이 직면하 고 있는 문제에는 어떠한 것이 있으며, 이를 위 한 향후 전랴은 어떠한 방향으로 전개되어야 하는지 살펴보고자 한다.

\section{1 〈참이슬〉과의 경쟁 전략}

브랜드 별 이미지 조사를 살펴보면, 〈처음처 
럼〉은 '순하다', '부드럽다', '알칼리수'의 요소에 서 높은 점수를 받아 〈처음처럼〉만의 이미지를 구축하고 있음을 알 수 있다. 하지만 〈처음처 럼〉에게 필요한'깨끗하다'의 이미지는 〈참이슬〉 에 대해 더욱 강하게 형성되어 있으며, '전통있 다', '대중적이다', '친근하다'의 요소에서도〈참 이슬>이 월등히 강한 이미지를 형성하고 있다. 〈처음처럼〉은 기존에 구축한 차별화된 이미지 를 유지하는 동시에, 이러한 차별적 이미지와 시너지를 일으킬 수 있는 이미지 오소를 강화 할 수 있는 마케팅 전략을 계획해야 한다.

〈처음처럼〉은 알찰리수를 주원료로 사용하여 '부드러운 목 넘김', '산성화 방지', '숙취 해소' 등과 같은 다양한 기능적 우위를 지니고 있어, 지금까지는 이러한 기능적 속성들을 강조하는 광고전략을 시행했으나, 이제는 이를 기반으로 '웰빙 소주'로서의 이미지를 강조하는 전략을 사용해야 한다. 소주의 경우 심한 알코올 냄새 가 주요 불만족 요인으로 꼽히고, 숙취로 인해 건강을 해친다는 인식이 많다. 소주 시장의 대 표 제품인 〈참이슬〉에 대한 소비자의 인식 역 시 소주에 대한 인식과 크게 다르지 않을 것이 다. 따라서 〈참이슬〉과 차별화하기 위해서〈처 음처럼>은 부드럽고, 숙취 해소를 돕는 '웰빙 소주'라는 이미지를 고객들에게 인식시키기 위 한 다양한 마케팅 전랴을 강구해야 한다.

\section{2 〈참이슬 fresh〉와의 경쟁 전략 방향}

〈참이슬〉측에서는〈처음처럼〉과 경쟁하기 위 하여 〈참이슬 fresh〉를 출시하였고, 현재 대대 적인 마케팅 전략을 펼치고 있다. 이로 인해 〈처음처럽〉의 주요 목표 고객이었던 20대들이
〈참이슬 fresh〉로 이탈하는 현상이 나타나고 있 다. 따라서 〈처음처럼〉은 20 대의 이탈을 방어하 기 위한 전략을 강구해야 한다. 이를 위해 20대 를 대상으로 소주 속성에 대한 중요도 및 브랜 드 뼐 만족도 조사를 실시해야 한다. 조사 결과 를 통해 20대가 중요하게 생각하는 속성은 무 엇이며, 이 중에서 〈처음처럼〉이 〈참이슬 fresh>에 비해 만족도가 낮은 것은 무엇인지 찾 아내고, 이를 향상시키기 위한 전략을 세워야 한다. 또한, 소비자조사를 바탕으로〈처음처럼〉 이 더욱 강화해야 할 이미지 요소는 무엇인지 확인하고, 관련 방안을 강구해야 한다. 그리고 20대들에게 〈처음처럼〉이 〈참이슬 fresh〉보다 제품력이 뛰어난 브랜드임을 강조하기 위하여, 현재 진행하고 있는'따라오려면 제대로 따라오 라'라는 식의 마케팅 전략과 더불어 더욱 다양 화되고 적극적인 마케팅 방안이 구상되어야 할 것이다.

〈논문 접수일: 2007. 09. 30〉 〈게재 확정일: 2007. 09. 30〉

\section{참고문헌}

다비트 보스하르트(2001), 소비의 미래 : 21세 기 시장 트렌드, 생각의나무. 두산 내부자료(2007), 처음처럼 성공사례. 로버트 B. 세틀, 파멜라 L. 알렉(2003), 소비의 심리학: 소비자의 코드를 읽는 12 가지 키 워드, 세종서적. 멜린다 데이비스(2003), 욕망의 진화, 21세기북 ㅅ. 
문숙재(2001), 소비자 트렌드 21세기, 시그마프 레스.

박충환, 오세조, 김동훈(2004), 시장 지향적 마 케팅 관리, 박영사.

사카이 나오키(2003), 감성 마케팅 잠든 시장을
깨운다, 정보공학

안광호, 김동훈, 김영찬(2006), 시장지향적 마케 팅전략; 학현사.

페이스 팝콘(2007), 미래 생활 사전, 을유문화사 